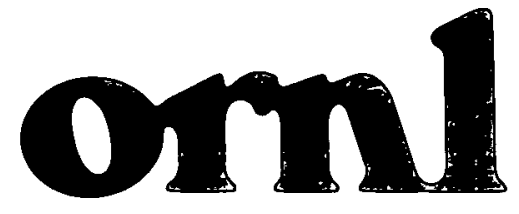

OAK RIDG扈 NATIONAB LABORATORY

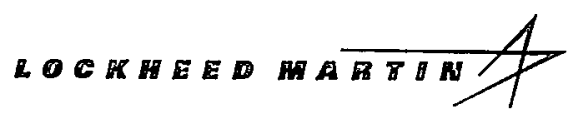

\section{U.S. DEPARTMENT OF ENERGY SUPERCONDUCTIVITY PROGRAM FOR} ELECTRIC SYSTEMS

\section{- PROCEEDINGS -}

\section{CRYOGENICS VISION WORKSHOP FOR HIGH-TEMPERATURE SUPERCONDUCTING ELECTRIC POWER SYSTEMS}

July 27, 1999

Loews L'Enfant Plaza Hotel

Washington, D.C.

Compiled by

Energetics, Inc. 
This report has been reproduced from the best available copy.

Reports are available to the public from the following source.

National Technical Information Service

5285 Port Royal Road

Springfield, VA 22161

Telephone 703-605-6000 (1-800-553-6847)

TDD 703-487-4639

Fax 703-605-6900

E-mail orders@ntis.fedworld.gov

Web site www.ntis.gov/ordering.htm

Reports are available to U.S. Department of Energy (DOE) employees, DOE contractors, Energy Technology Data Exchange (ETDE) representatives, and International Nuclear Information

System (INIS) representatives from the following source.

Office of Scientific and Technical Information

P.O. Box 62

Oak Ridge, TN 37831

Telephone 865-576-8401

Fax 865-576-5728

E-mail reports @adonis.osti.gov

Web site www.osti.gov/products/sources.html

Reports produced after January 1, 1996, are generally available via the DOE Information Bridge.

Web site www.doe.gov/bridge

This report was prepared as an account of work sponsored by an agency of the United States government. Neither the United States govermment nor any agency thereof, nor any of their employees, makes any warranty, express or implied, or assumes any legal liability or responsibility for the accuracy, completeness, or usefulness of any information, apparatus, product, or process disclosed, or represents that its use would not infringe privately owned rights. Reference herein to any specific commercial product, process, or service by trade name, trademark, manufacturer, or otherwise, does not necessarily constitute or imply its endorsement, recommendation or favoring by the United States govemment or any agency thereof. The views and opinions of authors expressed herein do not necessarily state or reflect those of the United States government or any agency thereof. 


\section{DISCLAIMER}

Portions of this document may be illegible in electronic image products. Images are produced from the best available original document. 


\author{
U.S. DEPARTMENT OF ENERGY \\ SUPERCONDUCTIVITY PROGRAM FOR ELECTRIC SYSTEMS
}

- PROCEEDINGS -

\title{
CRYOGENICS VISION WORKSHOP FOR HIGH-TEMPERATURE SUPERCONDUCTING ELECTRIC POWER SYSTEMS
}

July 27, 1999

Washington, D.C.

Date completed: December 1999

Date published: January 2000

Compiled by Energetics, Inc.

7164 Gateway Drive, Columbia MD 21046

(Subcontract 62X-SV815C)

for:

Superconductivity Program for Electric Systems

Oak Ridge National Laboratory

Oak Ridge, Tennessee 37831-6195

managed by

Lockheed Martin Energy Research Corporation for the

U.S. Department of Energy

under Contract DE-AC05-96OR22464

Research Funded by:

Office of Power Technologies

Office of Energy Efficiency and Renewable Energy

U.S. Department of Energy

(EB 5001000 ) 


\section{U.S. Department of Energy}

Superconductivity Program for Electric Systems

\section{CRYOGENICS VISION WORKSHOP FOR HIGH-TEMPERATURE SUPERCONDUCTING ELECTRIC POWER SYSTEMS}

\section{- Proceedings -}

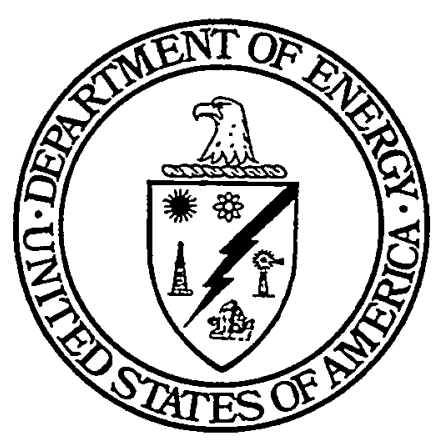

Loews L'Enfant Plaza Hotel Washington, D.C.

$$
\text { July 27, } 1999
$$




\section{CONTENTS}

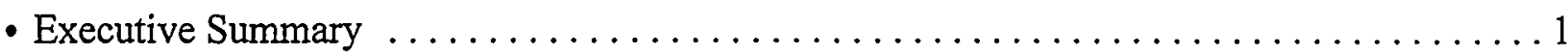

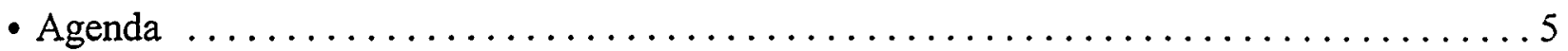

- Facilitated Sessions ........................................ 6

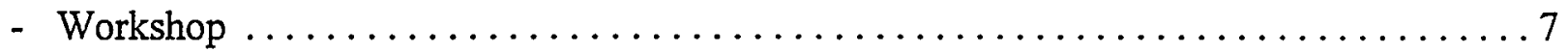

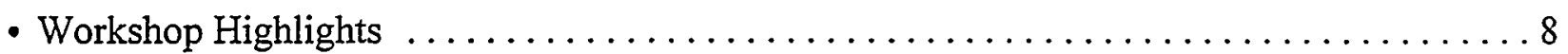

- Recap of Last Year's Workshop, "Cryogenics Needs of Future HTS Electrical Power

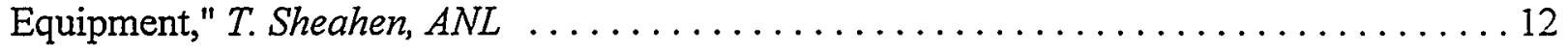

- Long Flexible Cryostat: Materials, Testing and Manufacture, J. Fesmire, NASA/KSC . . . 17

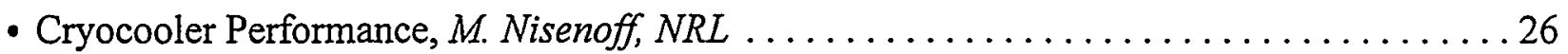

- Effects of Cryogenic Cost and Efficiency on the Competitiveness of High Temperature Superconductors (Early Results), J. Mulholland, DOE ................... 37

- Cryogenic System Issues for Utility Applications, N. Kelley, Pirelli and J. Jipling, Detroit Edison ................................................43

- Facilitated Vision Sessions ................................. 45

- What are the Critical Factors in a Shared Vision Statement for Successful Future Commercialization? ..................................... 49

- What Cryogenic System Goals are Needed to Meet Future Commercial HTS Equipment

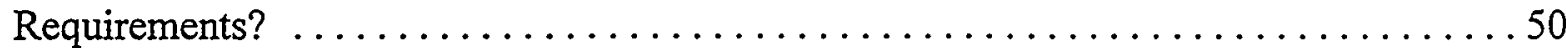

- What R\&D Activities Are Needed? ............................... 51

- What R\&D Partnership Roles Can Be Identified? ...................... 52

- Appendix A: Technology Roadmaps-Approaches and Lessons Learned, J. Badin,

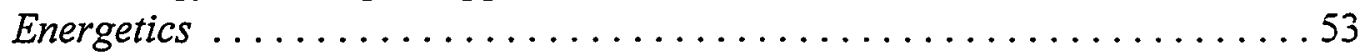

- List of Attendees .......................................... 77 


\section{Executive Summary}




\title{
CRYOGENICS VISION WORKSHOP
}

\author{
July 27, 1999
}

\section{EXECUTIVE SUMMARY}

The U.S. Department of Energy's Superconductivity Program for Electric Systems sponsored the Cryogenics Vision Workshop, which was held on July 27, 1999 in Washington, D.C. This workshop was held in conjunction with the Program's Annual Peer Review meeting. Of the 175 people attending the peer review meeting, 31 were selected in advance to participate in the Cryogenics Vision Workshops discussions. The participants represented cryogenic equipment manufactures, industrial gas manufacturers and distributors, component suppliers, electric power equipment manufacturers (Superconductivity Partnership Initiative participants), electric utilities, federal agencies, national laboratories, and consulting firms. Critical factors were discussed that need to be considered in describing the successful future commercialization of cryogenic systems. Such systems will enable the widespread deployment of high-temperature superconducting (HTS) electric power equipment. Potential research, development, and demonstration (RD\&D) activities and partnership opportunities for advancing suitable cryogenic systems were also discussed. The workshop agenda can be found in the following section of this report. Facilitated sessions were held to discuss the following specific focus topics:

- Identifying Critical Factors that need to be included in a Cryogenics Vision for HTS Electric Power Systems (From the HTS equipment end-user perspective)

- Identifying R\&D Needs and Partnership Roles (From the cryogenic industry perspective)

The findings of the facilitated Cryogenics Vision Workshop were then presented in a plenary session of the Annual Peer Review Meeting. Approximately 120 attendees participated in the afternoon plenary session. This large group heard summary reports from the workshop session leaders and then held a wrap-up session to discuss the findings, cross-cutting themes, and next steps. These summary reports are presented in this document. The ideas and suggestions raised during the Workshop will be used by the DOE Superconductivity Program for Electric Systems in preparing subsequent planning and strategy documents such as a Cryogenic Technology Development Roadmap.

\section{MAJOR FINDINGS}

- A modular, generic cryocooler design would be helpful if it can meet the needs for all applications.

- Reliability and safety are paramount to utilities. Maintenance intervals of 5 to 10 years are acceptable. Cryogenic system must be transparent to the user with fail-safe performance. 
- Need to know "What is the market?", "Who will buy it?" and "How big is this market in number of units and dollar value?"

- Utilities want to buy "cold" as a service. They desire reliable, low-cost solutions. There are cost trade-offs between hybrid and non-redundant systems.

- Cryogenics cost needs to be less than $10 \%$ of the total system cost.

- Efficiency goal should be $40 \%$ of Carnot efficiency. This may be achieved by reducing heat leak in half, understanding the losses, and using new types of compressors requiring less power consumption.

- System integration studies and designs need to be conducted. A cryogenic substation needs to be integrated.

- Dynamic operations of the cryosystem need to be studied, such as cool-down and recovery behavior in cases of perturbations.

\section{CONCLUSIONS AND NEXT STEPS}

- The Department should ensure that any new RD\&D efforts involving cryogenic systems take advantage of ongoing programs at the Navy Research Lab (NRL), the DOD Advanced Research Project Agency (ARPA), National Institute of Standards and Technology (NIST), NASA, national laboratories, and RD\&D at private companies. (See next page of recommendation from National Action Plan on Superconductivity).

- A vision and roadmap process for cryogenic systems, possibly modeled after the Industries of the Future initiative, could be useful in developing a cross-cutting R\&D plan. The Department should consider developing a draft cryogenics technology development roadmap from the information received at the Workshop and other information from the participants, and to then use the draft plan as a focal point in the vision and roadmap implementation process.

- Future meetings and workshops to encourage interactions between cryogenic system developers, utilities and potential users, power equipment manufactures and vendors, and government agencies could be beneficial in raising awareness about the critical window of opportunity that exists to have commercial-ready cryogenic systems available in order to ensure market acceptance of developed HTS electric power systems. 


\section{The National Action Plan on Superconductivity}

- Issued by Office of Science and Technology Policy (OSTP), Executive Office of the President, February 1991

- Major Recommendation for Compact Refrigeration: Increased attention should be paid to the development of the enabling technology of compact refrigeration to enhance the performance and reduce the cost of superconducting devices. DoD and NASA should continue to play leading roles in this activity. 


\section{Agenda}

- Facilitated Sessions

- Workshop 


\section{Cryogenics Vision for HTS Electric Systems Meeting \\ Facilitated Sessions - July 27, 1999}

\section{AGENDA}

$8: 30 \mathrm{am}-12: 45 \mathrm{pm}$

\begin{tabular}{|c|c|}
\hline $8: 30-10: 30 \mathrm{AM}$ & $\begin{array}{l}\text { Identifying the Cryogenics Vision for HTS Electric Power Systems } \\
\text { (Defining our end-point: HTS equipment needs-driven discussion) } \\
\text { Focus Question: What kind of future do we want to create for the cryogenic } \\
\text { refrigerator industry that will enable the widespread deployment of HTS electric } \\
\text { power equipment? } \\
\text { - What are the critical factors that need to be included in a shared vision statement } \\
\text { between cryogenic system suppliers and HTS equipment developers that describes } \\
\text { successful future commercialization? }\end{array}$ \\
\hline $10: 30-10: 45 \mathrm{AM}$ & Break \\
\hline $10: 45-12: 45 \mathrm{PM}$ & $\begin{array}{l}\text { Identifying R\&D Needs } \\
\text { (Defining how to reach our end-point: Cryogenic industry driven discussion) } \\
\text { Focus Questions: } \\
\text { - What cryogenic system goals are needed to meet future commercial HTS power } \\
\text { equipment requirements? } \\
\text { - What are the technical barriers in attaining a commercial cryogenic capability for } \\
\text { these power applications? } \\
\text { - What R\&D activities are needed to overcome the technical barriers? } \\
\text { - What R\&D partnership roles can be identified? }\end{array}$ \\
\hline $12: 45 \mathrm{PM}$ & Adjourn for Lunch \\
\hline 2:00-5:00 PM & Cryogenics Workshop \\
\hline
\end{tabular}




\title{
Cryogenics Vision for HTS Electric Systems Workshop
}

July 27, 1999

\section{AGENDA}

\author{
2:00-5:00 pm
}

\begin{tabular}{c|l}
\hline 2:00-2:10 PM & Introduction - J. Daley, DOE \\
\hline 2:10-2:30 PM & $\begin{array}{l}\text { Recap of Last Year's Workshop, “Cryogenics Needs of Future HTS Electrical Power } \\
\text { Equipment” - T. Sheahen, Western Technology Inc. }\end{array}$ \\
\hline 2:30-2:40 PM & Long Flexible Cryostat: Materials, Testing and Manufacture - J. Fesmire, NASA, KSC \\
\hline 2:40-2:50 PM & Cryogenic R\&D Activities at NRL - M. Nisenoff, NRL \\
\hline 2:50-3:15 PM & Technology Roadmaps - Approaches and Lessons Learned - J. Badin, Energetics, Inc. \\
\hline 3:15-3:30 PM & Break \\
\hline 3:30-4:30 PM & Report of Results from Facilitated Vision Meetings - Group Spokespersons \\
\hline 3:30-4:00 PM & Report and Discussion: Vision Statement \\
\hline 4:00-4:45 PM & Report and Discussion: Goals, R\&D Needs, Partnerships \\
\hline 4:45-5:00 PM & Next Steps - J. Daley, DOE \\
\hline 5:00 PM & Adjourn \\
\hline
\end{tabular}


Workshop Highlights 


\section{WORKSHOP HIGHLIGHTS}

On the afternoon of July 27,1999 , a workshop was held to examine the concept of forming a "roadmap" for future cryogenics R\&D. This followed two morning sessions attended by a select group in which certain aspects of the task were considered in more depth.

A year earlier, on July 22, 1998, a workshop took place that looked at the present state of the art in cryogenic refrigerators, and asked the Superconducting Partnership Initiative (SPI) participants to state what they foresaw as their future cryogenic needs. That conference (the proceedings of which have been published under the title Cryogenic Needs of Future HTS Electrical Power Equipment) is summarized in the next section.

The existence of a desired future state constitutes a goal, but so what? At this year's workshop, Dr. James G. Daley of DOE explained that we ask the question "How do we get from here to there?" Our goal is to produce a roadmap, and this 1999 workshop is the beginning of that process. Jim Daley also pointed out that there is no guarantee that $\mathrm{DOE}$ is going to conduct any particular research as a result of this effort; indeed, it is possible that DOE should not be involved in cryogenics research at all. Jim reminded the attendees that in 1991, OSTP basically said that NASA and DOD should lead the cryogenics effort. Thus, it is fair to ask at the outset: "What role, if any, should be assigned to the government, and to DOE in particular?" Because America already has a cryogenics industry, it must be recognized that one possible answer is "none!"

The role of NASA in contemporary cryogenics research was described by James Fesmire. NASA is focusing on insulation. NASA tests long lines (flexible or rigid) up to $40 \mathrm{~m}$ in length. For their applications, thermal performance dominates their criteria. Thermal insulation must be robust, and therefore several things need to be developed. In conventional devices, either foam or Multi-Layer Insulation (MLI) is used, and the $\mathrm{k}$-values are around 30 , which implies losses of about $0.1 \mathrm{~mW} / \mathrm{meter}-\mathrm{K}$. MLI has many drawbacks, but NASA hopes to reach a $\mathrm{k}$-value of $0.01 \mathrm{~mW} / \mathrm{meter}-\mathrm{K}$; in the lab, they've hit 0.05 , but in actual devices it's more like 0.1 . (All this is for systems running between $300 \mathrm{~K}$ and $77 \mathrm{~K}$.) Mr. Fesmire showed a chart on which 150 different tests were plotted; the values tended to coalesce around a certain relationship, at least on log-log paper. Jim Fesmire pointed out that the actual performance of a flexible cryostat is 3 to 10 times worse than you would like to expect. In conclusion, he noted that an overall heat leak of $1 \mathrm{~W} /$ meter is achievable, but not easy. NASA will continue its testing program, in cooperation with Oak Ridge National Laboratory.

Dr. Marty Nisenoff described ongoing cryogenics research at DOD. The military makes infrared detectors that operate at $77 \mathrm{~K}$, and there is a need to remove about 1 watt. However, the bigger applications are too big for the military at this time. Nisenoff reported that Carrier's Stirling cooler removes $350 \mathrm{~W} @ 77 \mathrm{~K}$, with only $3500 \mathrm{~W}$ input; this means the efficiency is above $30 \%$ of Carnot efficiency, which is quite good. More and more people are working on small cryocoolers. Pulse-tube Gifford McMahon (GM) machines are used to cool to $55 \mathrm{~K}$ and remove $15 \mathrm{~W}$.

Nisenoff also drew attention to the importance of cost: Knowing that large quantities drive the price down, you would have to manufacture 10,000 units to get the price down to $\$ 1,000$. A market of only 1,000 such units would be too small to interest the cryogenic manufacturers.

Marty made an additional point about reliability: It is important to use proven design concepts that really work in hardware. When you get to quantity production (hundred's per month), then you get high 
reliability. Between this and the cost, you cannot "technology push" here -- there has to be "market pull" if commercial applications are ever to be realized.

(Earlier, during a morning session, Carl Rosner of Intermagnetics General Corp. had sketched the history of MRI units. Their first unit was built in the 1960s, and needed refilling with liquid Helium weekly, because it lost 1 liter/hour of He. Today, their MRI units lose only $5-10 \mathrm{cc} /$ day, and need refilling every 3 to 5 years. That's good, sound engineering progress, of course; but it took 30 years to get there.)

Following the presentations about NASA and DOD research, Joe Badin of Energetics explained what a roadmap consists of: Basically, we define the endpoint and state where we are now, and then work backward. We seek to find the technology path that connects the two. To form a good roadmap, a collection of interested parties gets involved. The vision is to be defined by industry. A technology roadmap is a way to achieve that vision. Implementing this requires a multi-year action plan. There are complementary roles for industry and government. Government is a partner, not necessarily a sponsor. The government tends to facilitate, coordinate, leverage and disseminate results; but the real work gets done by industry. Various "industries of the future" have constructed roadmaps; Joe Badin cited some examples. A workshop such as this is a tool to get you to the roadmap, not the roadmap itself. It is important to get the right people together for the task.

Following a break, the two morning meetings were summarized.

1. First Nathan Kelley of Pirelli Cable discussed the vision meeting. The basic question was "What will the cryocoolers of the future look like?" A modular, generic design would be helpful, one that meets everyone's needs; but their own project (cables) may not have exactly the same needs as other applications. To the utilities, reliability and safety are paramount. What will have to be proved before the cryosystem is acceptable? We need to ask how to make the cryogenic system "transparent" to the user. Also, we must ask "What is the market?" and "Who will buy it?"

For the most part, the utilities just want to buy "cold" as a service -- they don't care about the details. However, the system needs to be unmanned, with no intervention by utility technicians required. But having the "cheapest" solution is not the only criterion. We must ask whether a customer wants on-site refrigeration, or trucked-in LN2. The idea of a hybrid system, combining a cryocooler with LN2 backup, was considered more reliable; the roadmap should examine the cost trade-off between hybrid and non-redundant systems.

Other criteria include maintenance, where 5 to 10 years intervals is expected; on the electronics side, 3 to 5 years is acceptable. It is desirable to "swap and drop" at maintenance times. Utilities are not going to have a staff of trained cryo-engineers.

Kelley also reported that the morning meeting had examined the trade-off between reliability and temperature. For example, if you're already at $77 \mathrm{~K}$, is it worth it to spend money on a mechanical system to reach $70 \mathrm{~K}$ or $64 \mathrm{~K}$ ? Certainly, the roadmap needs to look at temperatures other than $77 \mathrm{~K}$.

Among other things, the operating requirements call for running at ambient temperatures up to $75 \mathrm{C}$. Moreover, the footprint must be small for the cryosystem to be acceptable.

\section{The second morning session, dealing with $R \& D$ needs, was summarized by Ken Kreinbrink of PHPK Technology. He enumerated several priorities:}

1. The first goal is to reduce cost. The cryogenics needs to comprise less than $10 \%$ of the total system cost. For example, a $600 \mathrm{~W}$ system should cost under $\$ 70,000$. 
2. Efficiency needs to increase. We think we can get $30 \%$ of Carnot efficiency; we'd like to reach $40 \%$.

3. Most operating systems will be at $77 \mathrm{~K}$ or above.

4. The system needs to operate for 5 years without maintenance, so it must be very simple and very reliable. We want fail-safe performance, too; can that requirement tolerate delivery of cryogens?

5. There must be system integration, for example in the design of a hybrid system.

Another way to express this is to observe that there are five things to do:

A. Cut the heat leak in half.

B. The cryogenic substation needs to be integrated together.

C. Efficiency: understand the losses, in order to get $30 \%$ or $40 \%$ efficiency.

D. Dynamic environment: study cool-down and recovery of the cryosystem in case of perturbations.

E. Equipment R\&D: new types of compressors with less power consumption, etc.

Following these presentations, Tom Sheahen presided over a general discussion from the floor, wherein the concerns of the HTS community could be voiced.

The next step is to form a working group who will actually produce the roadmap. 


\section{Recap of Last Year's Workshop}

"Cryogenics Needs of Future HTS Electrical Power Equipment," T. Sheahen, ANL 


\section{Summary of 1998 Workshop:}

\section{Cryogenics Needs of Future \\ HTS Electric Power Equipment}

July 22, 1998

This workshop addressed the question: Will practical cryogenic refrigerators be available to meet the needs of emerging superconducting power systems over the next five to ten years? Dr. Christine Platt chaired the event.

There were two panels, consisting of

a) SPI partners making HTS devices, and

b) Cryogenic manufacturers.

Marty Nisenoff of Naval Research Laboratory gave a Kevnote Presentation. describing the R\&D goals of DARPA. aimed toward low-cost. high-reliability cryocoolers. In a pair of memorable lines reminiscent of the movie Field of Dreams, Nisenoff characterized the current relationship between users and manufacturers as:

HTS Community: "If we will build it (HTS systems) they (cryocooler community) will come:

Cryocooler community: "If they (HTS community) will come with large orders. we will build it (low-cost, reliable cryocoolers).

Any goal looks much more attainable on log-log paper, and that is certainly true of cryocoolers and their cost. Figure 1 here is taken from Nisenoff's presentation, and shows where coolers are today and what the DARPA goals are.

Another useful summary appears in Table 1: this is a summary of Cryocooler Requirements as stated by the SPI partners building each of the HTS applications. It was compiled after the 1998 workshop, with entries drawn from the presentations.

Each of the two panels consisted of a series of presentations by the panelists. The slides that each speaker showed are assembled in the volume of the Workshop Proceedings, and adequately describe those talks.

Open discussion among all the attendees followed the second panel. The intent of that discussion was to identify the most important issues for further attention. Pp. 139141 of the Proceedings enumerate some of the major points of discussion. The topics broke into two broad categories: Performance Gaps and Technology Development Needs. The key points are as follows:

Obvious: Reduce the heat load!

Higher efficiency, greater reliability and smaller size are always needed. 
Since the electrical load varies, so does the cooling load. A variable coolingpower capability is desirable.

There is a "gap" in available cryocoolers between $100 \mathrm{~W}$ and $1 \mathrm{~kW}$. For most SPI projects. the cooling requirement lies in between Gifford-McMahon and Brayton-cycle units. The feasibility of scaling up small systems or scaling down large systems needs to be explored. Pulse-tube refrigerators and closed-loop Stirling cycles are particularly interesting here.

The losses in transformers are so small to begin with that the available $i^{-2} R$ savings will be squandered on cooling losses unless the refrigeration system is very small.

Cables have a large surface area per unit length, and generate a large thermal load. $50 \mathrm{~kW}$ is a typical requirement, so the refrigeration system will comprise a significant percentage of the total cost.

Cryogenic manufacturers are confident they can build suitable refrigerators, but they await evidence of real demand for their systems before going ahead with the expense of development efforts.

Research needed includes: better insulation; and better transport of fluids in a cryogenic environment.

"There needs to be a collaborative approach in working with HTS equipment manufacturers. cryogenic system manufacturers, the national labs and DOE."

The 1999 Workshop is intended to take up where the 1998 Workshop left off. Specifically, we need to answer two questions:

What exactly is needed to meet the cryogenic needs of future HTS power devices? And

What program of collaborative R\&D will get us there?

Of course it is exceedingly difficult to say that some R\&D path will reach a goal. The activity of roadmapping is an endeavor to set goals, identify the obstacles to success, and devise a plan for overcoming them. A good roadmap will say what each partner will contribute to the R\&D effort, and in what time-frame. Our purpose in holding the 1999 Workshop is to begin the process of making that roadmap. 


\section{Cryocooler Cost/Life Performance}

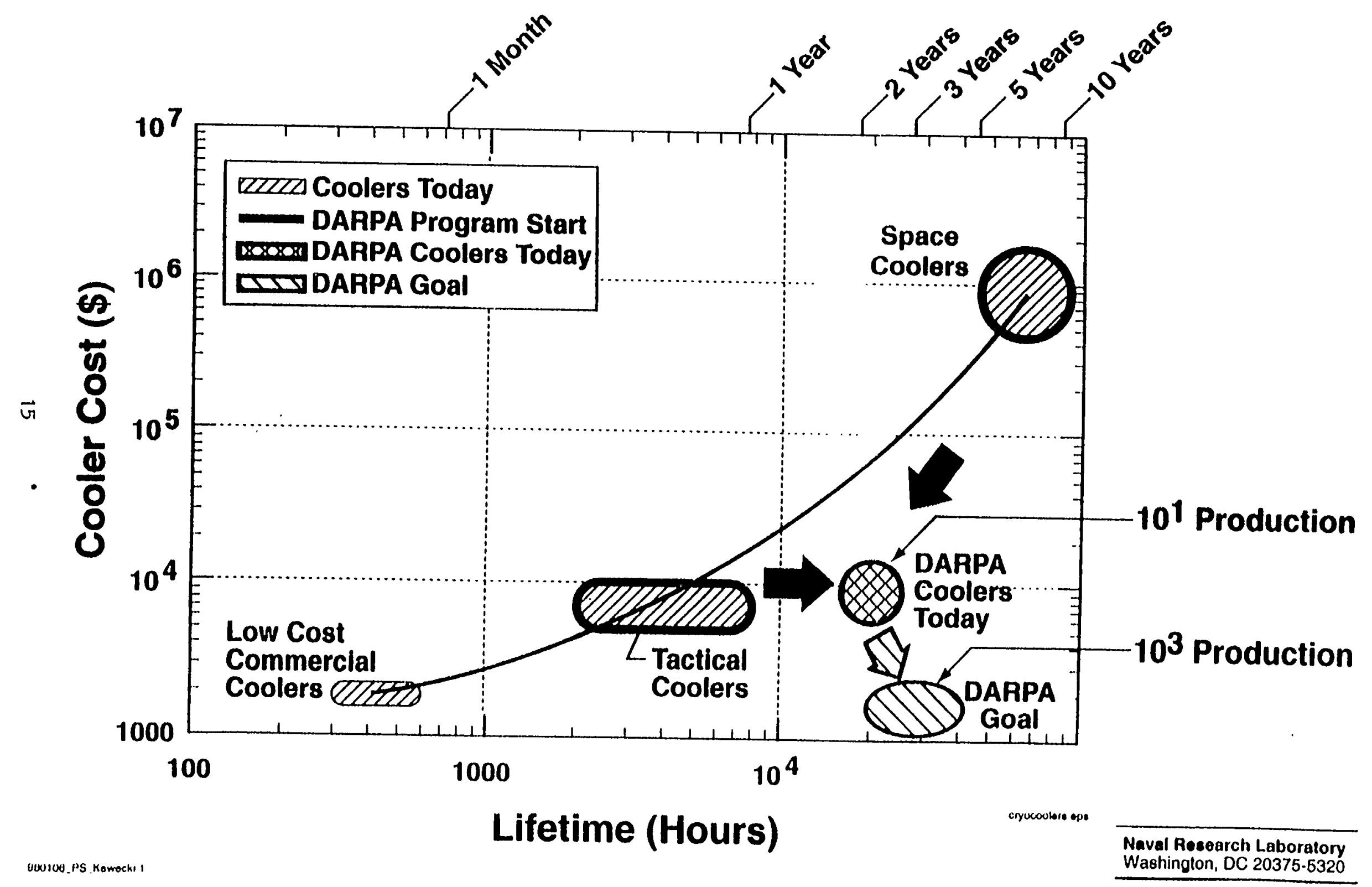


TABLE 1

Summary of Cryocooler Requirements

\begin{tabular}{|c|c|c|c|c|c|}
\hline & \multicolumn{5}{|c|}{ HTS APPLICATIONS } \\
\hline Requirements & Motor & $\begin{array}{c}\begin{array}{c}\text { Fault-Current } \\
\text { Limiter }\end{array} \\
\end{array}$ & Transformer & Cable & Flywheel \\
\hline Cost (Capital) & $\$ 25.000$ & $\$ 55,000$ & $\begin{array}{c}<20 \% \text { of total } \\
\text { cost }\end{array}$ & $\begin{array}{l}\$ 20.000^{(0)} / \mathrm{kW} \\
\text { cold power }\end{array}$ & $\begin{array}{l}\$ 2.000 \\
\$ 10.000\end{array}$ \\
\hline Temperature & $<33 \mathrm{~K}$ & $30-60 \mathrm{~K}$ & & $\begin{array}{c}67 \mathrm{~K} \\
\text { pressure: } 5-25 \\
\text { bar }\end{array}$ & $70-77 \mathrm{~K}$ \\
\hline $\begin{array}{l}\text { Power (Cooling at } \\
\left(\begin{array}{c}\left.T_{20}\right)\end{array}\right.\end{array}$ & $<10 \mathrm{~kW}$ & $15 \mathrm{~kW}$ & & & $1 \mathrm{~W} / \mathrm{kWh}$ \\
\hline Periormance & $60 \mathrm{~W}$ & $\begin{array}{l}280 \mathrm{~W} \text { at } 60 \mathrm{~K} \\
15 \mathrm{~W} \text { at } 30 \mathrm{~K}\end{array}$ & & $\begin{array}{c}5-10 \mathrm{~kW} / \mathrm{km} \\
5 \mathrm{~kW} \text { (pilot } \\
\text { system) } \\
50 \mathrm{~kW} \text { (large } \\
\text { scale) }\end{array}$ & \\
\hline Reliability & 9,000 hrs $^{(b)}$ & 10,000 hrs $^{(9)}$ & & 26,000 hrs $^{\text {es }}$ & \\
\hline $\begin{array}{l}\text { Operating } \\
\text { Environment }\end{array}$ & $313 \mathrm{~K}$ & $323 \mathrm{~K}(\max )$ & & $313 \mathrm{~K}$ & \\
\hline Size & Compact & & & $\begin{array}{l}\text { Compact for } 50 \\
\mathrm{~kW} \text { cold power } \\
9 \times 9 \times 3.5 \mathrm{~m}\end{array}$ & $\begin{array}{c}1 \mathrm{ft}^{3} \\
\left(a \text { few } \mathrm{tt}^{3}\right)\end{array}$ \\
\hline
\end{tabular}

"Three G-M cycle cryocoolers (single coil)

'MTBF: meantime between falures

" MTBM: meantime between maıntenance

$\Rightarrow$ Target investment cost. Today for $20 \mathrm{~kW}$ cold power investment $\$ 60,000 / \mathrm{kW}$ cold power. O\&M should be $5-8 \%$ of the total svestment per year.

" About 3 years for maintenance: 40 year operating life 


\section{Long Flexible Cryostat:}

Materials, Testing and

\section{Manufacture}

J. Fesmire, NASA/KSC 


\title{
Long Flexible Cryostat
}

C'ryogenicsTestbed

Jolun F. Kennedy Space Center

\section{Long Flexible Cryostat: Materials, Testing, and Manufacture}

\author{
TEAM \\ Karen Thompson, NASA Kennedy Space Center \\ Maria Littlefield, NASA Kennedy Space Center \\ James Fesmire, NASA Kennedy Space Center \\ Stan Augustynowicz, Dynacs Engineering Co. at NASA KSC
}




\section{Long Flexible Cryostat}

CryogenicsTestbed

Jolnn F. Kennedy Space Center

\section{Introduction}

- Main Point: Bring together aspects of the refrigeration side and the conductor side, along with operations and maintenance considerations, for lowest total cost.

- Second Main Point: Consider the energy balance of the total system over its lifetime for accurate economic trade-off of subsystems.

Insulate $($ insulatus $)=$ to set apart, detach from the rest, isolate 


\section{Long Flexible Cryostat}

CryogenicsTestbed

Jolun F. Kenuedy Space Center

\section{Cryogenics Testbed Capabilities at the NASA Kennedy Space Center}

- Network of industry, aerospace, and research partners

- Test Facilities

- Materials evaluation

- Systems integration, controls, and data acquisition

- Design and operation points of view

- Cryogenics Test Laboratory

- Cryostat-1, for thermal conductivity measurement of thermal insulation

- Cryostat-2, for evaluation of cryogenic insulation systems

- Pipeline Test Apparatus, for long (40 m) rigid or flexible lines 


\section{Long Flexible Cryostat}

CryogenicsTestbed

Jolin F. Kennedy Space Center

\section{Power Transmission Application}

- Urban retrofit application is initial market.

- Design the long flexible cryostat for power transmission over medium to long distances (from $100 \mathrm{~m}$ to $1000 \mathrm{~m}$ ) for 30 years service life.

- Top level requirements

- Flexible, bellows inside bellows

- May be segmented at intermediate points with rigid lines

- No feed-through connections allowed

- Very limited maintenance at long intervals

- Manufacturing must be practical and at reasonable cost 


\section{Long Flexible Cryostat}

CryogenicsTestbed

Jolun F. Kemedy Space Center

\section{Thermal Insulation System}

- Thermal performance considerations

- Refrigeration system.

- Liquid nitrogen flow through corrugated and rigid lines

- Thermal insulation system

- Materials: Thermal insulation and vacuum enclosure must be "robust"

- Testing: Determine performance margins and limits for basic questions such as outgassing, possibility of cryogen flow change from 1-phase to 2-phase, compression effect as a function of bending radius, extra mechanical support structures, variation of apparent thermal conductivity (k-value) in the annular space.

- Example: Vacuum only, $\mathrm{k}$-value is up to $5 \mathrm{~mW} / \mathrm{m}-\mathrm{K}$; Standard MLI, $\mathrm{k}$-value is as low as 0.1 $\mathrm{mW} / \mathrm{m}-\mathrm{K}$. [For cold vacuum pressure (CVP) below $1 \times 10^{-4}$ torr and boundary temperatures of approximately $300 \mathrm{~K}$ and $77 \mathrm{~K}$ ]

- Manufacturing: Methods will determine actual performance, cost, and service life. Economic trade-offs are numerous here, but first.... What are the limiting factors with today's technology? 


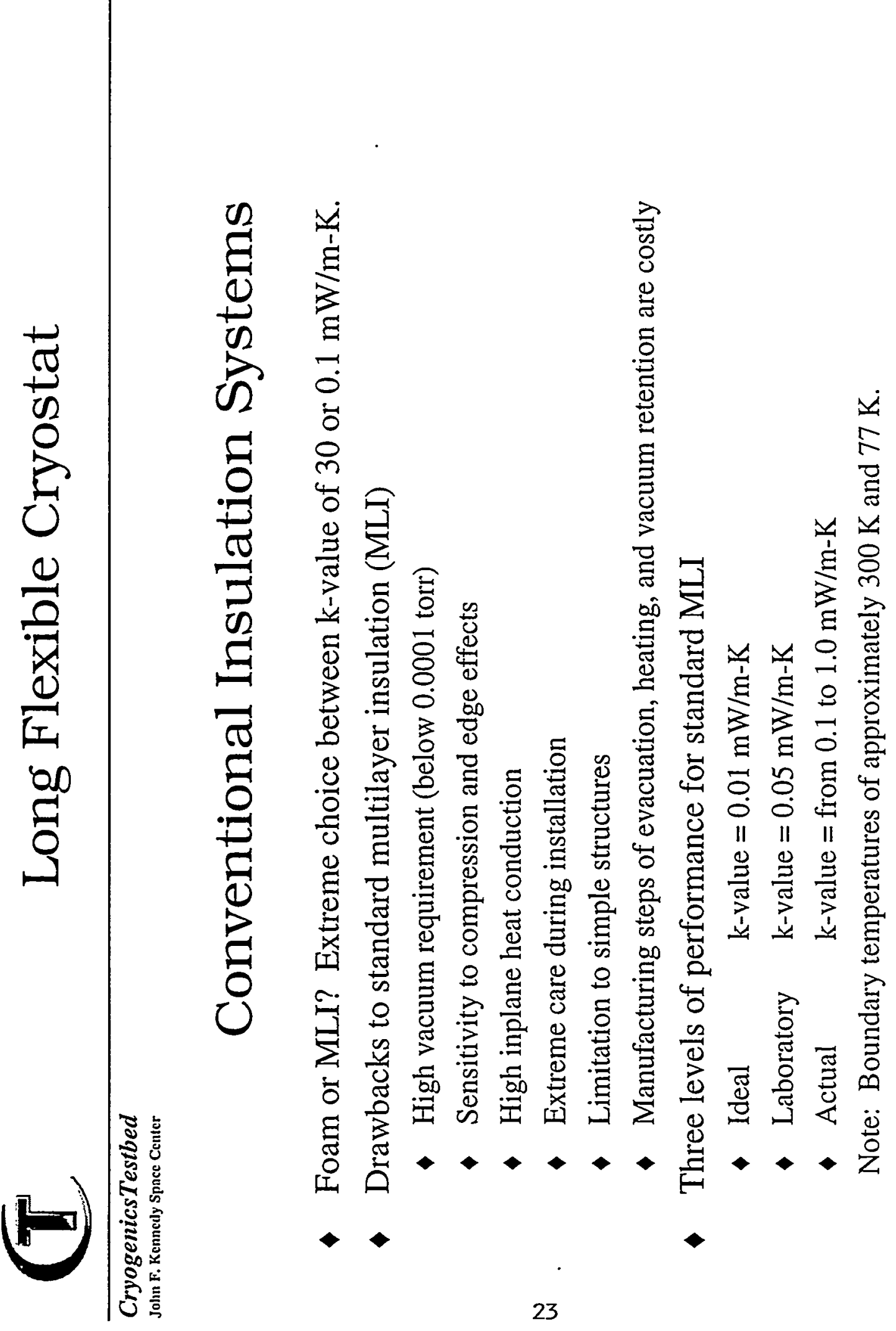




\section{Long Flexible Cryostat}

\section{Thermal Insulation System Testing (extracted results)}

\begin{tabular}{|c|c|c|c|c|c|c|}
\hline CVP & k-value & $\Delta \mathbf{T}$ & $(\mathrm{Q} / \mathrm{L}) \mathrm{ins}$ & $(\mathrm{Q} / \mathrm{L})_{\mathrm{s} \text { truc }}$ & $(\mathrm{Q} / \mathrm{A})$ ins & $(\mathrm{Q} / \mathrm{A})_{\text {struc }}$ \\
\hline (torr) & $(\mathrm{mW} / \mathrm{m}-\mathrm{K})$ & $(\mathrm{K})$ & $(\mathrm{W} / \mathrm{m})$ & $(\mathrm{W} / \mathrm{m})$ & $\left(\mathrm{W} / \mathrm{m}^{2}\right)$ & $\left(\mathrm{W} / \mathrm{m}^{2}\right)$ \\
\hline \multicolumn{7}{|c|}{ Standard Multi-layer Insulation } \\
\hline $1 \times 10^{-4}$ & 0.08 & 194 & 0.42 & $\mathrm{n} / \mathrm{a}$ & 0.70 & $\mathrm{n} / \mathrm{a}$ \\
\hline 1 & 9.0 & 104 & 25.2 & $\mathrm{n} / \mathrm{a}$ & 42.0 & $\mathrm{n} / \mathrm{a}$ \\
\hline \multicolumn{7}{|c|}{ Cryogenic Insulation System } \\
\hline $1 \times 10^{-4}$ & 0.09 & 190 & 0.42 & $\mathrm{n} / \mathrm{a}$ & 0.69 & $n / a$ \\
\hline 1 & 2.4 & 179 & 10.5 & $\mathrm{n} / \mathrm{a}$ & 17.3 & $\mathrm{n} / \mathrm{a}$ \\
\hline \multicolumn{7}{|c|}{ Syntactic Foam Composite } \\
\hline 1 & 12.8 & 112 & 23.4 & $\mathrm{n} / \mathrm{a}$ & 35.9 & $n / a$ \\
\hline 760 & 24.4 & 90 & 35.9 & $\mathrm{n} / \mathrm{a}$ & 55.0 & $\mathrm{n} / \mathrm{a}$ \\
\hline \multicolumn{7}{|c|}{ Typical Vacuum Insulated Piping (RIGID, 4"x 6") } \\
\hline $1 \times 10^{-4}$ & $0.34^{*}$ & 220 & $\mathrm{n} / \mathrm{a}$ & .1 .25 & $\mathrm{n} / \mathrm{a}$ & 2.84 \\
\hline \multicolumn{7}{|c|}{ Typical Vacuum Insulated Piping (FLEX, 4"x 6") } \\
\hline $1 \times 10^{-4}$ & $1.02 *$ & 220 & $\mathrm{n} / \mathrm{a}$ & 3.71 & $\mathrm{n} / \mathrm{a}$ & 8.46 \\
\hline- & lue for & ield & & & & \\
\hline
\end{tabular}




\section{Long Flexible Cryostat}

CryogenicsTestbed

Jolun F. Kennedy Space Center

\section{Conclusions}

- Overall heat leak of around $1 \mathrm{~W} / \mathrm{m}$ is achievable but manufacturing and maintenance can be a problem due to the high vacuum requirement (below 0.0001 torr).

- Soft vacuum (1 to 10 torr) systems have much less "vacuum burden" costs which must be considered in the overall cost effectiveness of building, operating, and maintaining the long flexible cryostat.

- Basic heat transfer and fluid flow questions regarding the performance of flexible lines versus rigid lines should be addressed

- Testing program in collaboration with ORNL is planned

- System design to meet requirements of cable and refrigeration equipment

- Thermal analysis

- Testing and evaluation of performance under static and dynamic flow conditions 


\section{Cryocooler \\ Performance \\ M. Nisenoff, NRL}




\section{STATUS OF DOD AND COMMERCIAL CRYOGENIC REFRIGERATORS \\ M. Nisenoff}

M. Nisenoff Associates P.O. Box 2748 Kensington MD 20896-2748

DoE Superconductivity Program for Electric Systems Annual Peer Review Meting

Washington DC

27 July 199 


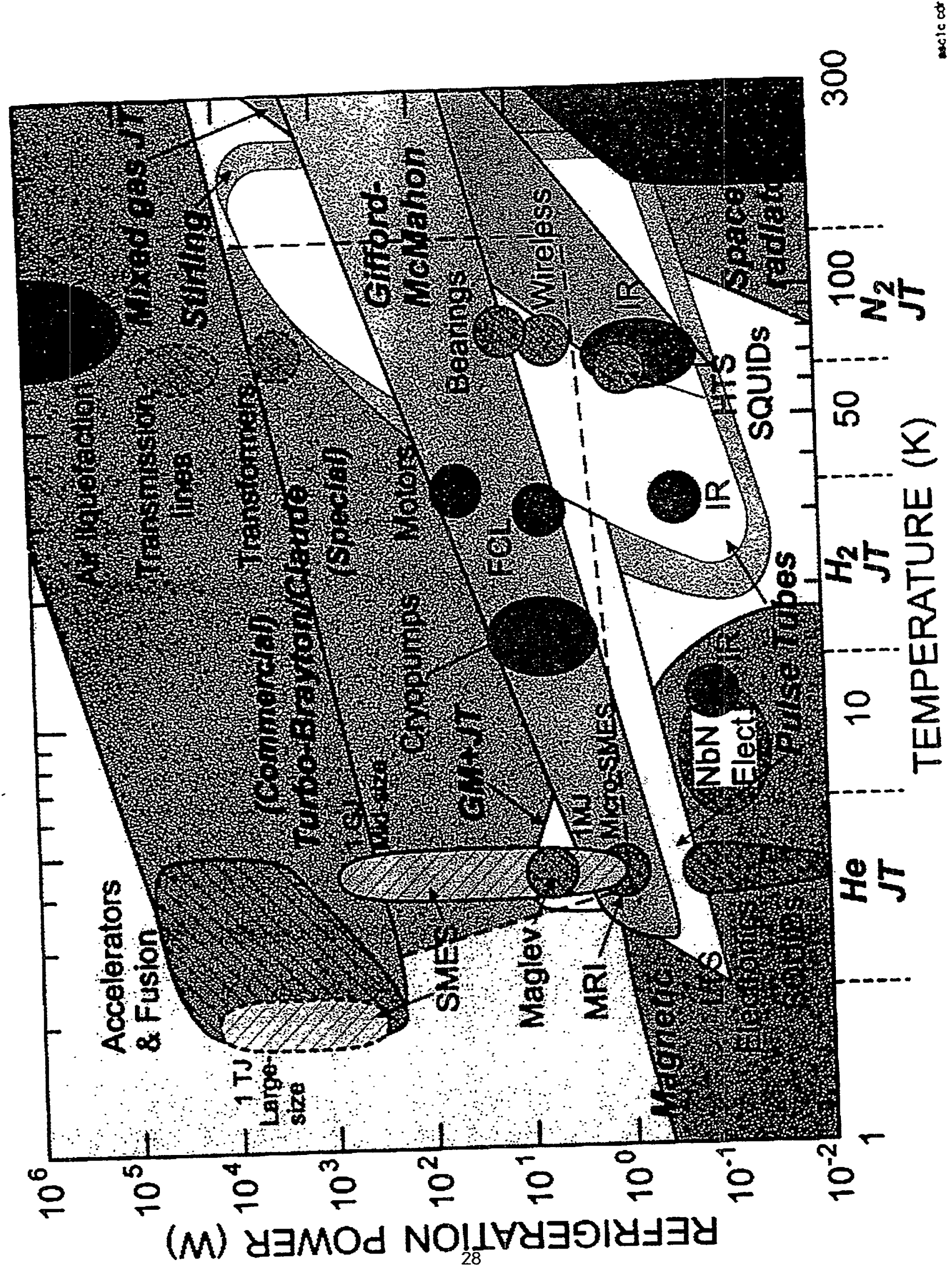




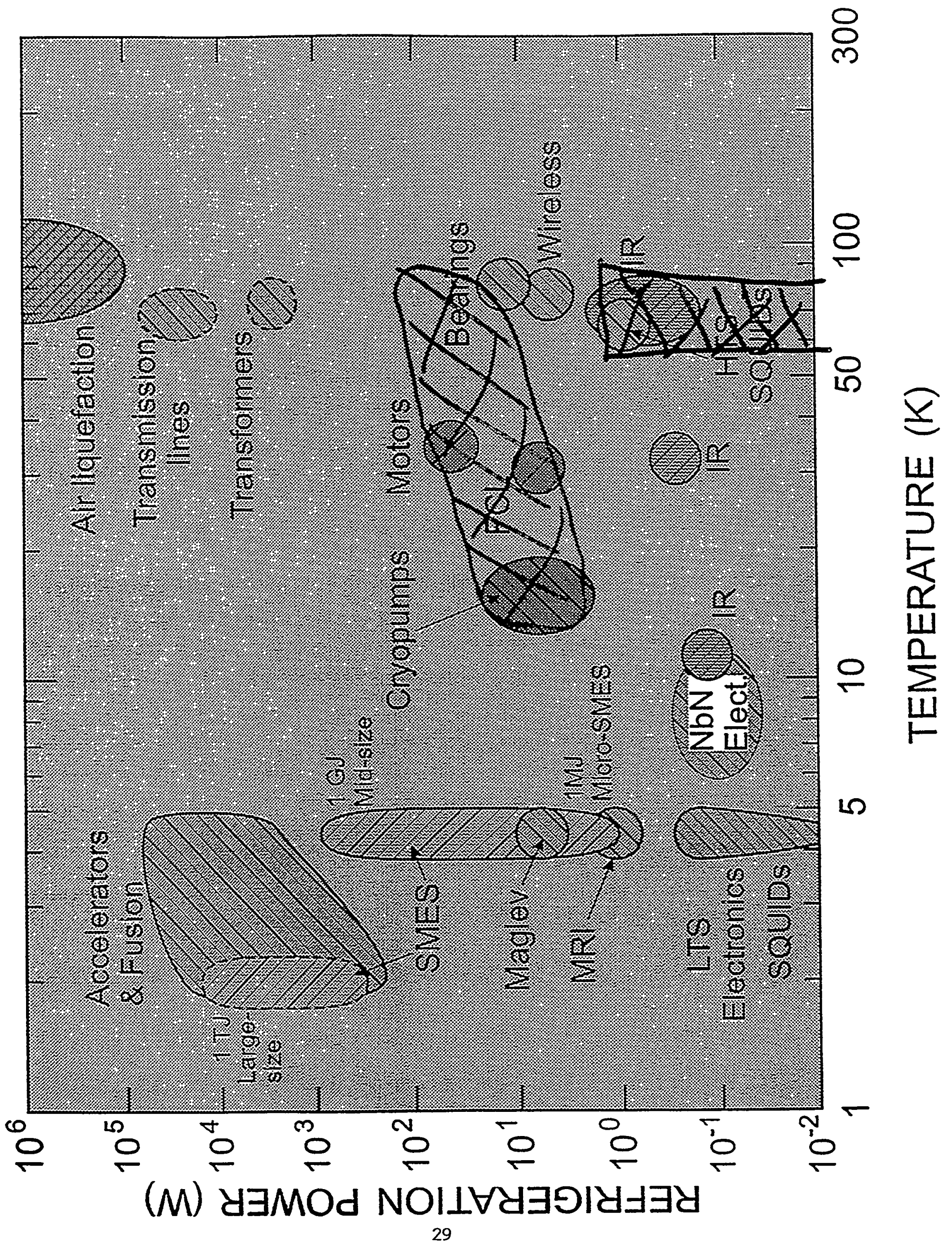




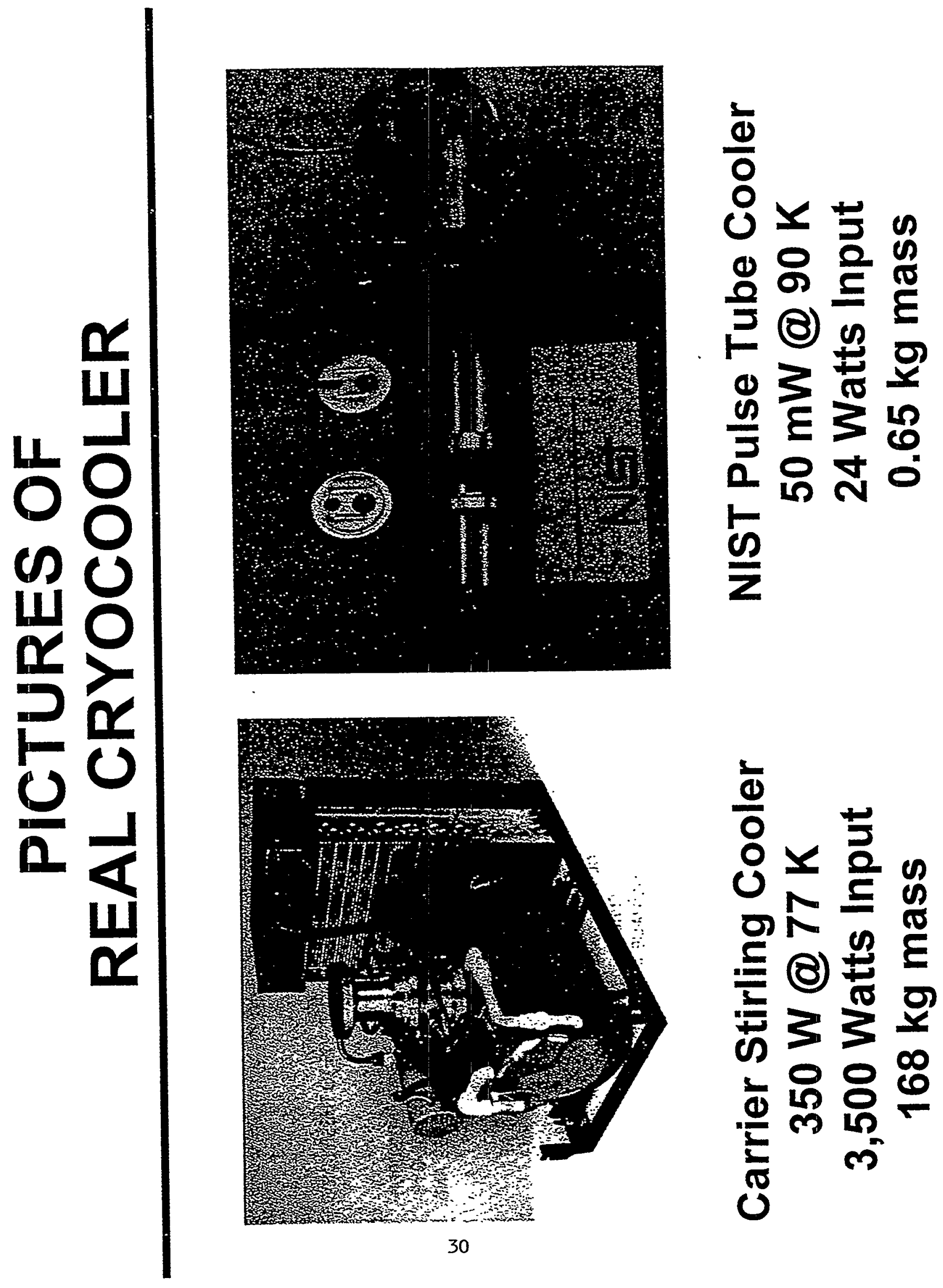




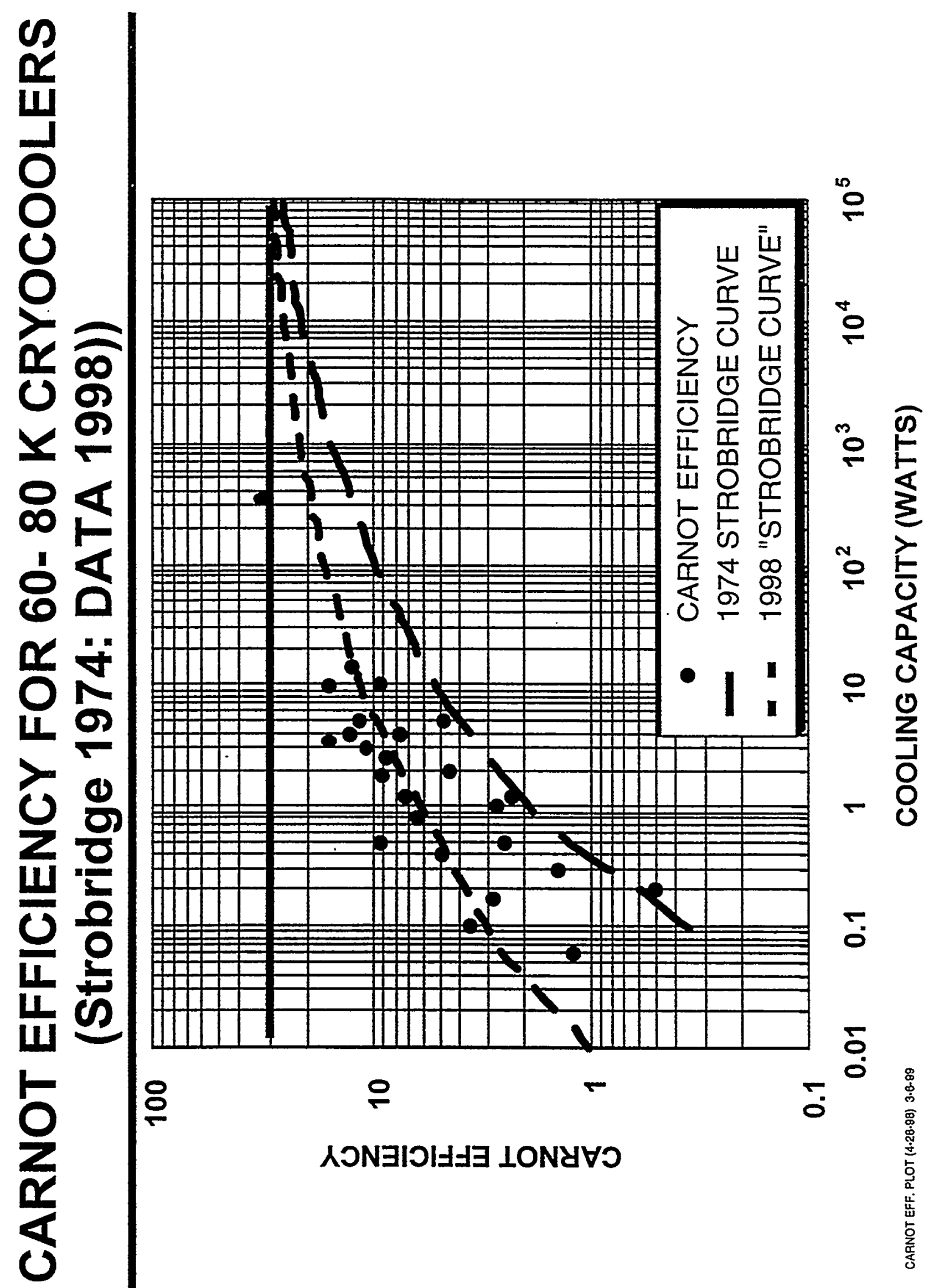




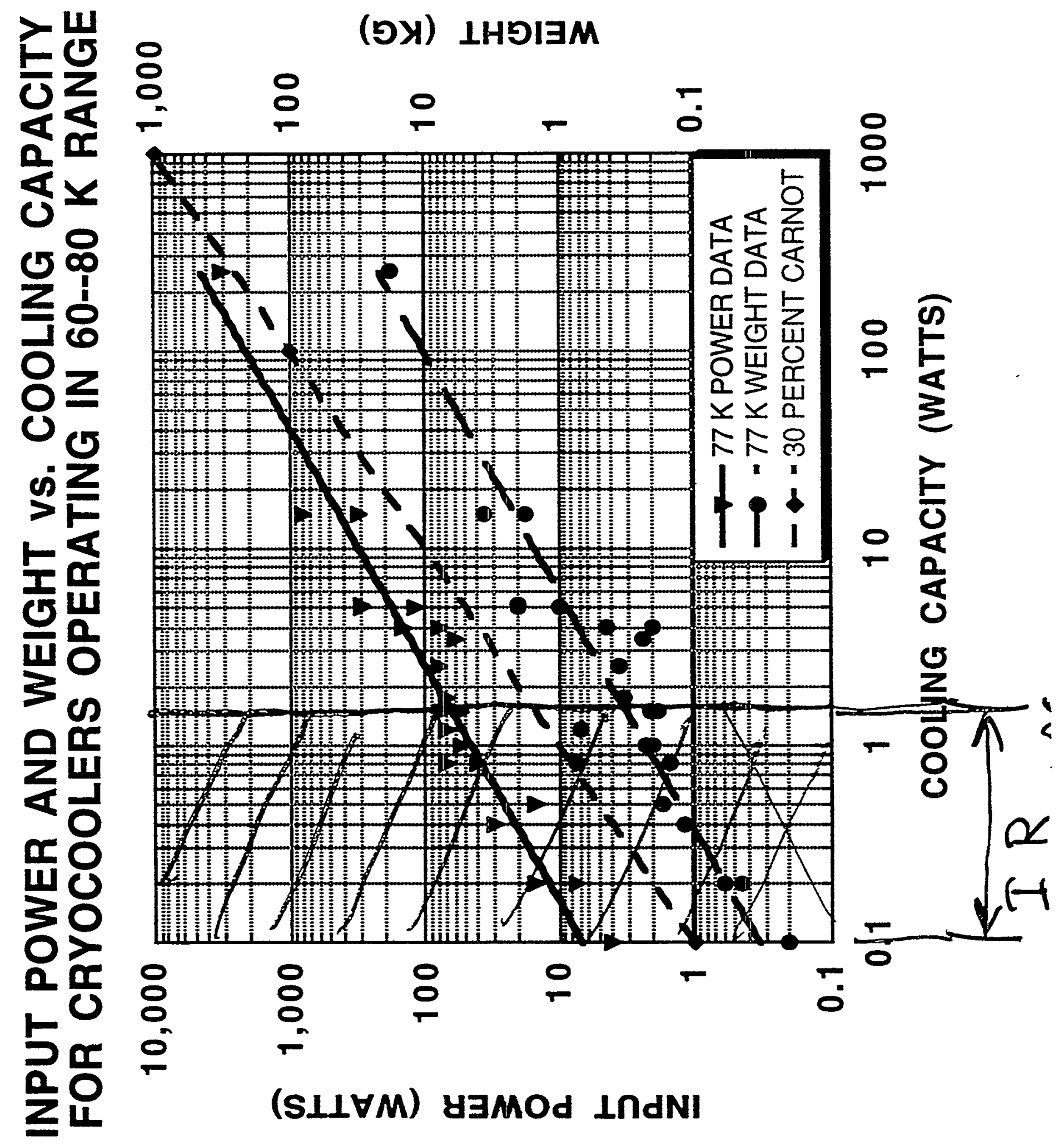


IN-LINE SOLVAY COLD HEAD
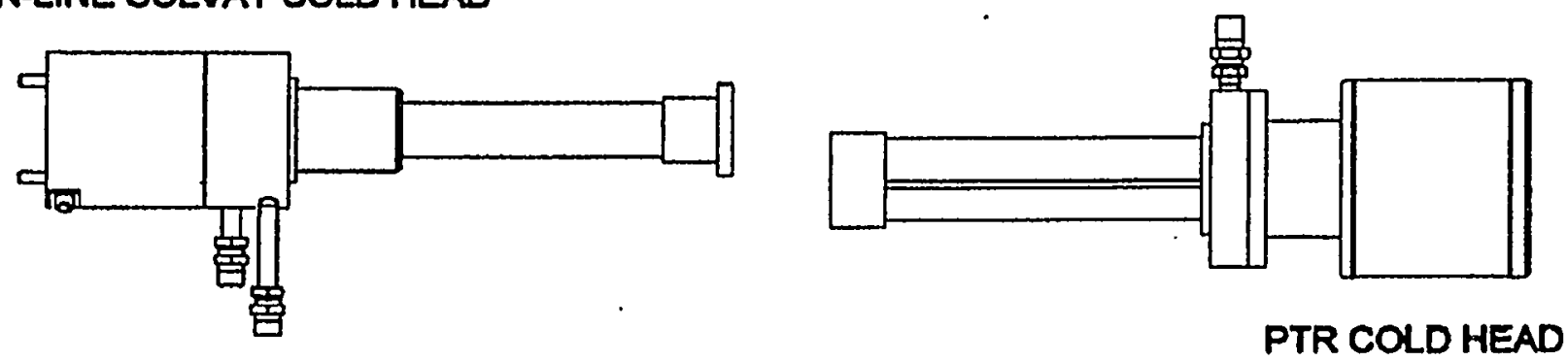

Pulse Tube Refrigerator (PTR) Cryocoolers

\begin{tabular}{|c|c|c|c|c|c|c|c|c|c|c|c|}
\hline \multirow{2}{*}{$\begin{array}{l}\text { Itom } \\
\text { No. }\end{array}$} & \multirow{2}{*}{$\begin{array}{l}\text { Head } \\
\text { Modd } \\
\text { No. }\end{array}$} & \multicolumn{2}{|c|}{ Q watts } & \multicolumn{2}{|c|}{ Ult Tomp. } & \multirow{2}{*}{\begin{tabular}{|c|}
$\pi m e$ to \\
$T_{\text {mk. }}$ \\
min
\end{tabular}} & \multirow{2}{*}{$\begin{array}{c}\text { Wgt, } \\
\text { kg }\end{array}$} & \multicolumn{2}{|c|}{ Dimenstons } & \multirow{2}{*}{$\begin{array}{l}\text { Comp: } \\
\text { Nodel } \\
\text { No. }\end{array}$} & \multirow{2}{*}{$\begin{array}{l}\text { AC } \\
\text { Poner, } \\
\text { watt }\end{array}$} \\
\hline & & $\begin{array}{l}\text { 1st } \\
\text { strtK }\end{array}$ & $\begin{array}{l}\text { 2nd } \\
920 \mathrm{~K}\end{array}$ & $\begin{array}{c}1 s t_{1} \\
K\end{array}$ & $\begin{array}{l}\text { 2nd, } \\
K\end{array}$ & & & $\mathrm{Lm}$ & $\begin{array}{l}\text { Dla., } \\
\text { mm }\end{array}$ & & \\
\hline $\begin{array}{l}13 \\
14 \\
15 \\
18 \\
17 \\
18 \\
18 \\
20\end{array}$ & $\begin{array}{c}\text { P201 } \\
\text { P201 } \\
\text { P301 } \\
\text { P301 } \\
\text { P301 } \\
\text { 2xP050" } \\
\text { P050 } \\
\text { P050 }\end{array}$ & $\begin{array}{c}0123 \mathrm{~K} \\
80123 \mathrm{~K} \\
2 \\
2 \\
10 \\
25 \\
10 \\
10\end{array}$ & 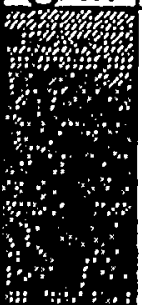 & $\begin{array}{l}77 \\
77 \\
66 \\
55 \\
60 \\
55 \\
55 \\
55\end{array}$ & 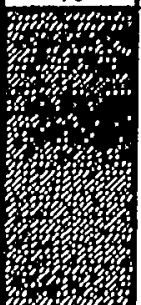 & $\begin{array}{l}25 \\
25 \\
30 \\
30 \\
30 \\
35 \\
36 \\
35\end{array}$ & $\begin{array}{l}1.2 \\
1.2 \\
1.3 \\
1.3 \\
1.3 \\
6 \\
0 \\
0\end{array}$ & $\begin{array}{l}200 \\
200 \\
250 \\
250 \\
250 \\
375 \\
375 \\
375\end{array}$ & $\begin{array}{c}70 \\
70 \\
70 \\
70 \\
79 \\
123 \\
123 \\
123\end{array}$ & $\begin{array}{l}\text { CA201 } \\
\text { CW301 } \\
\text { CN201 } \\
\text { CW301 } \\
\text { CW303 } \\
\text { CW303 } \\
\text { CA201 } \\
\text { CW301 }\end{array}$ & $\begin{array}{l}800 \\
700 \\
800 \\
700 \\
2300 \\
2300 \\
800 \\
700\end{array}$ \\
\hline
\end{tabular}

This is 2 cotd he eds connected to a single compressor.

Helium Compreseors for Solvay, PTR, and LN $_{2}$ Systems

\begin{tabular}{|c|c|c|c|c|c|c|c|c|}
\hline \multirow{2}{*}{$\begin{array}{l}\text { Itom } \\
\mathrm{Na} \text {. }\end{array}$} & \multirow{2}{*}{$\begin{array}{l}\text { Comp. } \\
\text { Mode } \\
\text { No. }\end{array}$} & \multirow{2}{*}{$\begin{array}{c}\text { AC } \\
\text { Porner, } \\
\text { wates }\end{array}$} & \multirow{2}{*}{$\begin{array}{l}\text { VAC } \\
(10) \\
\text { coHz }\end{array}$} & \multicolumn{3}{|c|}{ Dimensions } & \multirow{2}{*}{$\begin{array}{c}\text { Wot, } \\
\mathrm{kg}\end{array}$} & \multirow{2}{*}{$\begin{array}{c}\text { Water } \\
\text { Fow, } \\
\text { Lhr }\end{array}$} \\
\hline & & & & $\begin{array}{c}W_{1} \\
\mathrm{~mm}\end{array}$ & $\begin{array}{c}D_{1} \\
\mathrm{~mm}\end{array}$ & $\underset{\mathrm{mm}}{\mathrm{H}_{1}}$ & & \\
\hline $\begin{array}{l}21 \\
22 \\
23 \\
24\end{array}$ & $\begin{array}{l}\text { CA201 } \\
\text { CW301 } \\
\text { CW303 } \\
\text { CW306 }\end{array}$ & $\begin{array}{l}000 \\
700 \\
2300 \\
4000\end{array}$ & $\begin{array}{l}110 \\
110 \\
220 \\
220\end{array}$ & $\begin{array}{l}330 \\
380 \\
313 \\
450\end{array}$ & $\begin{array}{l}400 \\
420 \\
585 \\
505\end{array}$ & $\begin{array}{l}368 \\
445 \\
660 \\
697\end{array}$ & $\begin{array}{c}36 \\
45 \\
75 \\
130\end{array}$ & $\begin{array}{l}100 \\
200 \\
400\end{array}$ \\
\hline
\end{tabular}

Sold by: Kelvin Intematlonal Corporation P.O. Box 4008 - Hampton, VA 23684 USA

Tol: (757) 851-6216 or (800) 8-KELVIN

E-mall: Intoekohinic.com

Fox: (757) 851-5212 or (888) O-KIC FAX 


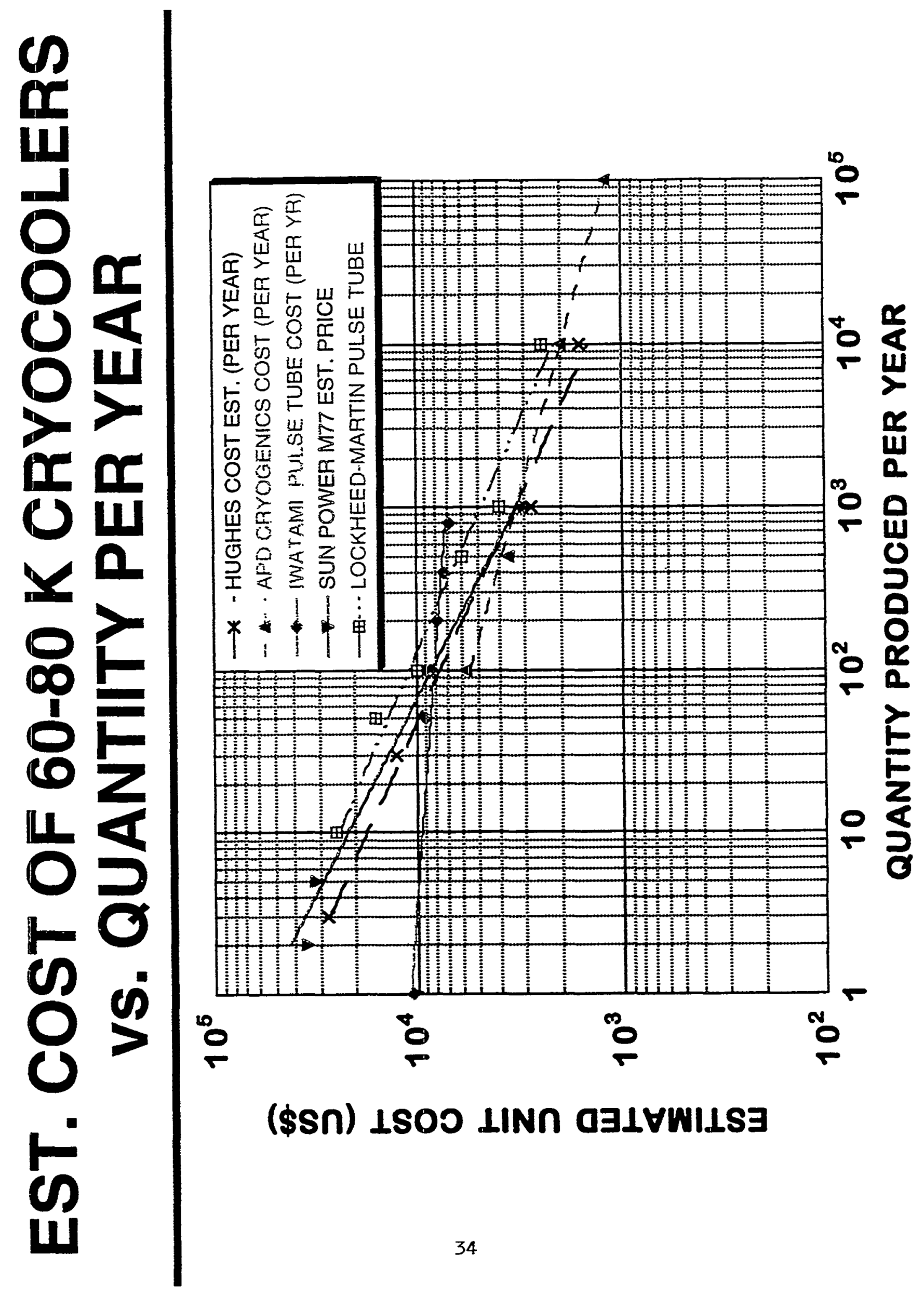




\section{THE REALITY OF LOW-COST HIGH- RELIABILITY CRYOCOOLERS}

- SEVERAL WELL-KNOWN THERMODYNAMIC CYCLES (Stirling, pulse tube, Gifford-McMahon, Joule-Thomson, Brayton, etc.)

- SOUND MANUFACTURING PROCEDURES

- Proven design concepts

u - - Design for large quantity production

- Sound manufacturing procedures

- LARGE QUANTITY PRODUCTION

- Production runs of 100's per month or greater

- Quantity production leads to

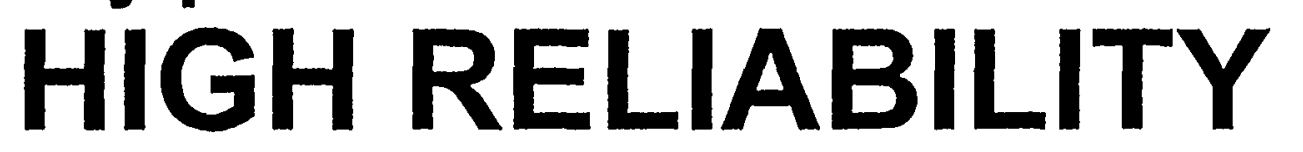

- Quantity production leads to

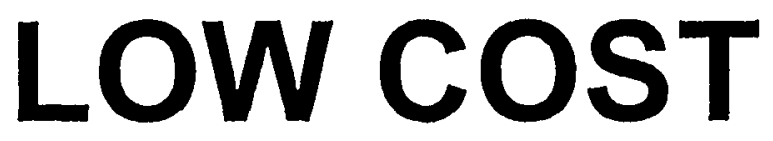




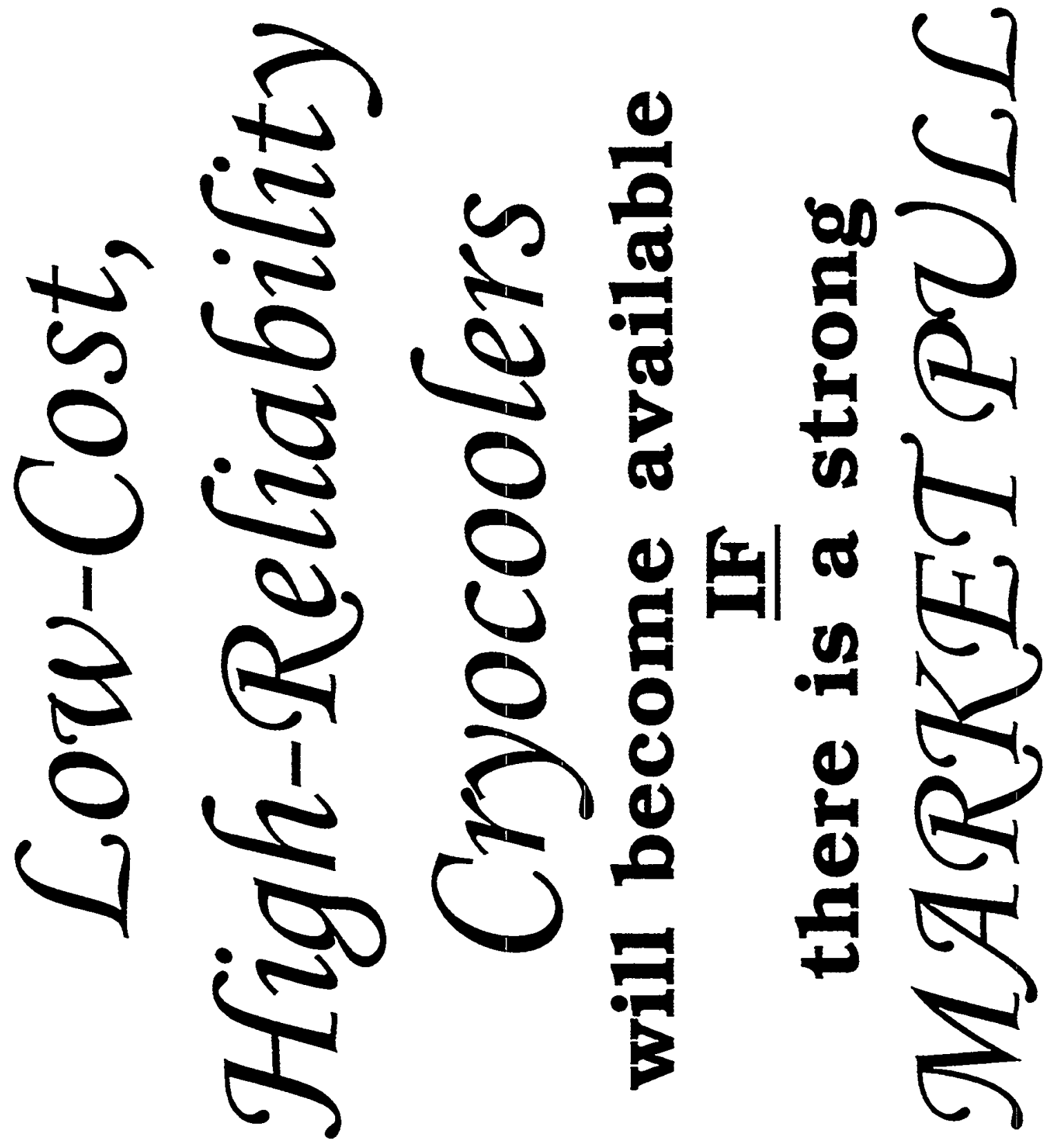




\section{Effects of Cryogenic Cost and Efficiency on the Competitiveness of High Temperature $\underline{\text { Superconductors (Early Results) }}$}

J. Mulholland, DOE 


\section{EFFECTS of CRYOGENIC COST \& EFFICIENCY on the COMPETITIVENESS of HIGH TEMPERATURE SUPERCONDUCTORS}

HTS wire break-even cost increases $\$ 5.45 / \mathrm{m}$ for every $1.0 \%$ of Carnot increase in efficiency of cryocoolers.

HTS wire break-even cost increase $\$ 3.44 / \mathrm{m}$ for every $\$ 1000 / \mathbf{k W}_{\text {но }}$ increase in capital cost of cryocoolers.

Silver costs $\$ 3.88 / \mathrm{m}$ of HTS BSCCO wire $(\mathrm{Ag}=\$ 5.50 / \mathrm{Tr}$. Oz.). 

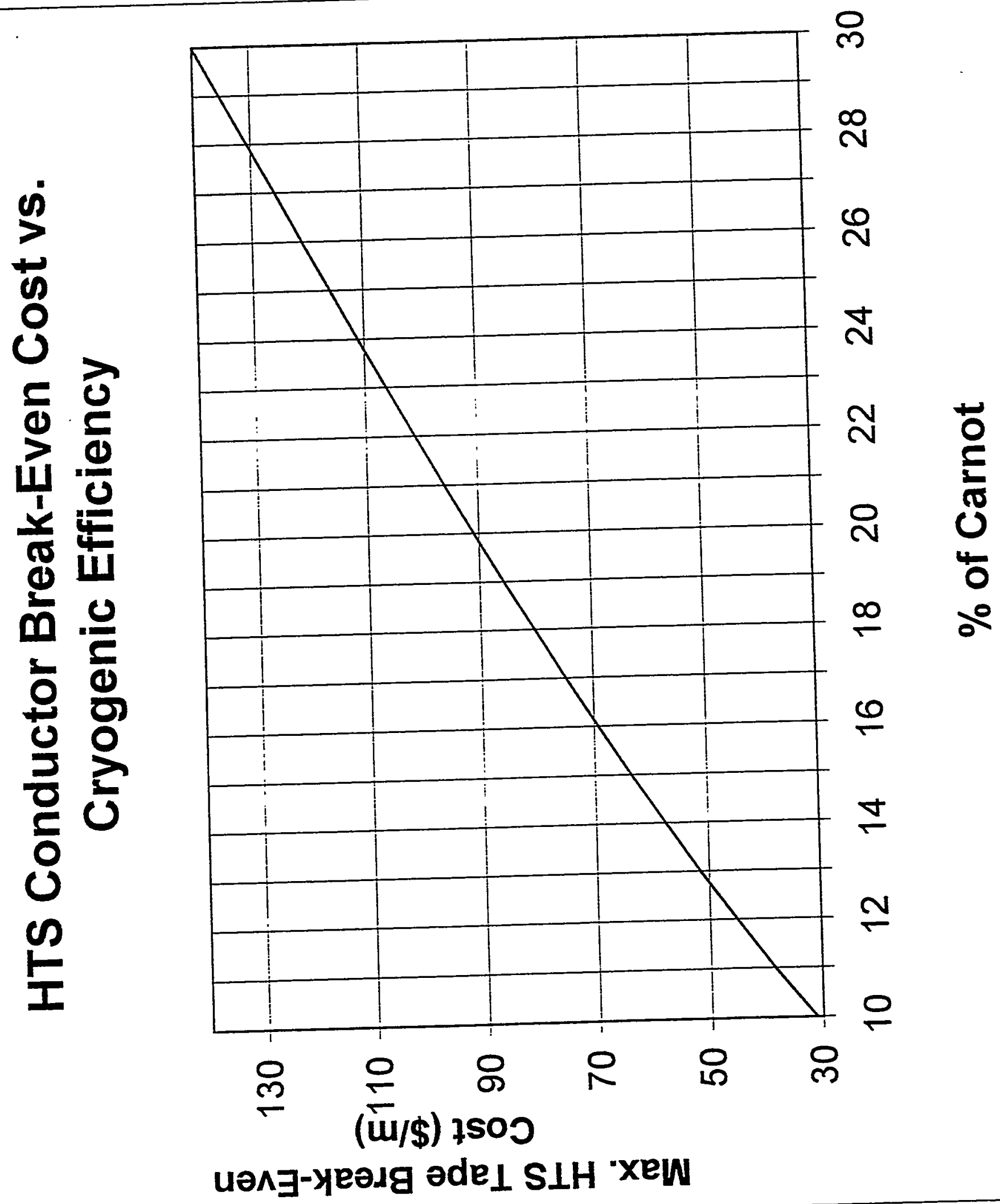


\section{Increase in Number of Cryogenic Units Required Each Year}

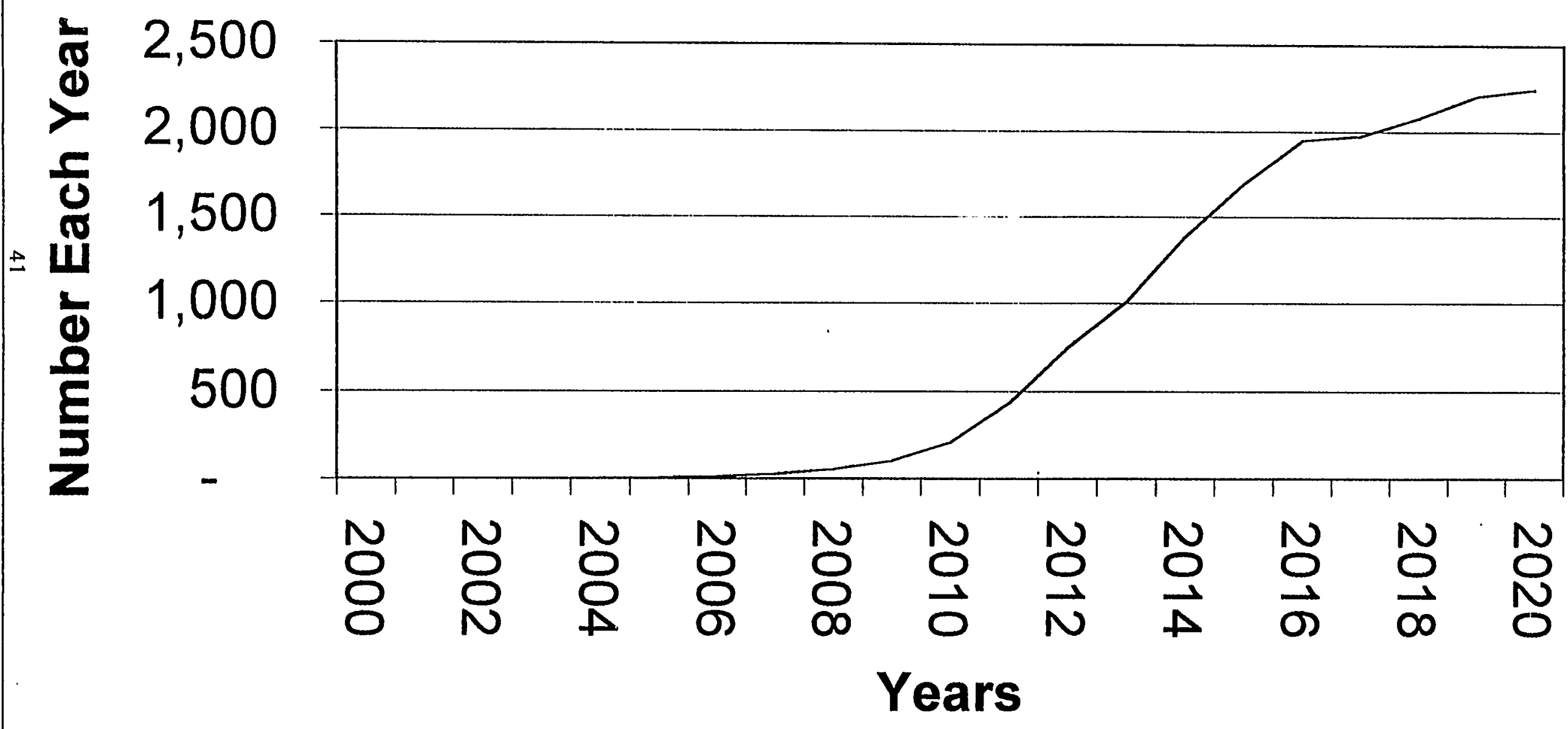




\section{DRAFT}

\section{Capacity of Cryogenic Units Required}

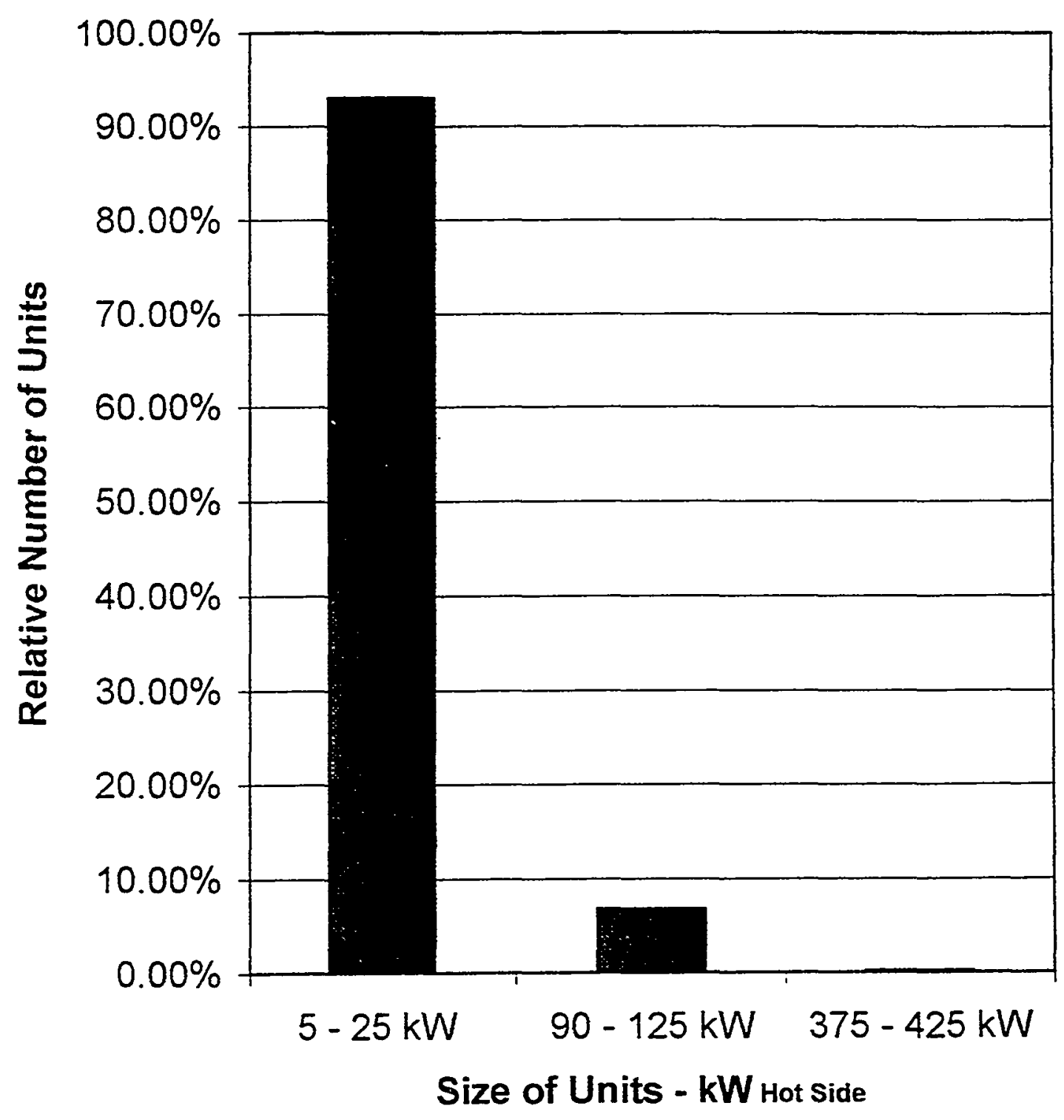




\section{Cryogenic System Issues for Utility Applications}

N. Kelley, Pirelli and J. Jipling, Detroit Edison 


\section{Cryogenic System Issues for Utility Applications}

1) HTS technologies are frequently cited for applications in congested regions. Therefore, the size of the refrigeration unit is a critical factor.

2) HTS cables' long length to volume ratio and restricted diameter make the continuous flow of $\mathrm{LN}_{2}$ critical.

3) A refrigerator should be capable of operating for very long periods of time without external intervention or attention, as most utility locations are unmanned.

4) System should be designed (and guaranteed) for $100 \%$ availability.

5) The load on a refrigerator will change depending on the cable load from a minimum (equal to the thermal inleak of the system) to a maximum design point. The system must operate efficiently through this entire range and reliably follow the continuously changing load.

6) The relatively high heat loads for HTS cables requires an efficient refrigerator, not only at design load, but at all operating points. This is particularly significant for cables with daily and/or seasonal dips in loading. The overall system efficiency must be improved from the generally quoted $20 \mathrm{~W} / \mathrm{W}$, as the life-cycle cost must be competitive with conventional cables.

7) The system should be able to provide larger refrigeration capacity for a short duration following transient thermal conditions, such as short circuit.

8) A system needs to be "low profile". This means that the refrigerator be as compact as possible. And, growing vertically is not always a solution.

9) Most utilities would not permit a third party (i.e. a $\mathrm{LN}_{2}$ vendor) to make deliveries without their personnel being present. And, it is not feasible for a substation operator to be available every three days for the $\mathrm{LN}_{2}$ refill. Subsequently, evaporative bath coolers are typically not an option as primary refrigerators.

10) Automatic circuit breakers and reconnects require some cycles to operate. The refrigerator cannot go through a complete shut-down/start-up cycle every time that the power "flickers".

11) The power requirements for different cable installations could be very different. Despite the capacity differences, it is important that there be standardization of spare parts and repair techniques.

12) Other HTS technologies are operating below $\mathrm{LN}_{2}$ temperatures, and so will use He based systems. Different cycles or refrigerator types for cables, transformers, etc. would require large parts inventory and diverse training.

13) Major components and long-lead items will need to be stocked, because a system cannot be outof-senvice for several months waiting for replacement components.

14) The utility maintenance infrastructure will need training on routine and emergency maintenance.

15) For widespread commercial deployment of refrigeration systems, a skilled field-service force will be required.

16) System availability and reliability should be very high.

17) COST!!! Final system cost must be competitive on first installed and life-cycle basis.

18) Typical utility hardware has a 40-year depreciation. Refrigerator longevity will be compared to this experience.

19) The utilities have little experience with cryogenics and refrigeration. Therefore, they have many questions and doubts. The cryogenics industry must be willing and able to work with system developers to educate the end users.

20) Remote control system capability should be integrated in the refrigeration system. Utilities are spending a lot of money to install remote monitoring and automation on their distribution systems. The refrigeration system must easily integrate with a variety of monitoring systems and protocols. 


\section{Facilitated Vision}

- What are the Critical Factors in a Shared Vision Statement for Successful Future Commercialization?

- What Cryogenic System Goals are Needed to Meet Future Commercial HTS Equipment Requirements?

- What R\&D Activities Are Needed?

- What R\&D Partnership Roles Can Be Identified? 


\section{FACILITATED ViSION SESSION}

The purpose of the facilitated sessions was to discuss the key aspects of cryogenic system development. Specifically, the group discussed: 1) critical factors to be included in a vision statement for the cryogenic industry that will allow the successful future commercialization of HTS electric power equipment; 2) cryogenic system cost and performance goals needed to meet future commercial HTS equipment requirements; 3) needed $R \& D$ activities and priorities and 4) identification of $R \& D$ partnership roles. As shown on the next page, the 31 participants (and 3 observers) represented a variety of different perspectives and included individuals with experience and expertise from the business, government, and academic arenas.

Participants were given the focus questions on the agenda which formed the basis of the discussion, a list of 20 cryogenic system issues for utility applications, and a background defining discussion terms such as key drivers, vision, and strategic goals. These pages are included in this section.

Following the background pages are tables summarizing the discussion points for each focus question:

- What are the critical factors in a shared vision statement for successful future commercialization?

The most critical factor identified by the group was reliability. Cryogenic systems should be transparent to the user and have low-cost maintenance and have a 5-10 year maintenance cycle. Utilities want "cold" service without additional burdens. There is a need to understand the market requirements, system integration issues, and trade-offs in cost, reliability, and safety in having a hybrid system combining a cryocooler with the $\mathrm{LN}_{2}$ back-up versus non-redundant systems.

- What cryogenic system goals are needed to meet future commercial HTS equipment requirements?

Goals were discussed for system parameters such as cost, efficiency, variable loads and demands, operating temperature, market, fail-safe performance, complexity, reliability, safety, flexibility, compactness, performance, and monitoring and control.

\section{- What $R \& D$ activities are needed?}

Priorities were established for the R\&D activities by allowing the participants to "vote." On the corresponding table, votes are shown as "stars." R\&D activities are presented from highest to lowest priority (as determined by the participants).

\section{- What $R \& D$ partnership roles can be identified?}

The government role for the five highest priority $R \& D$ activities was identified by the group. The government role ranged from developing fundamental knowledge to prototype funding as well as funding novel and risky ideas. 


\section{CRYOGENICS VISION WORKSHOP PARTICIPANTS}

\begin{tabular}{l}
\multicolumn{1}{c}{ Name } \\
\hline Tim Atkinson \\
S. Augustynowicz \\
Jonathan Demko \\
Ronald den Heijer \\
James Fesmire \\
Pter Gifford \\
Paul Grant \\
George Harriott \\
Michael Heil \\
Jon Jipping \\
Nathan Kelley \\
Peter Kerney \\
Ken Kreinbrink \\
Ron Lee \\
Eddie Leung \\
Maria Littlefield \\
Ralph Longsworth \\
Jerry Martin \\
Marty Nisenoff \\
Ray Radebaugh \\
V.R. Ramanan \\
Christopher Rey \\
John Royal \\
John Stovall \\
Mike Strasik \\
Ahmed Sidi-Yekhlef \\
Robert Thorogood \\
Michael Troy \\
Steven Van Sciver \\
Philip Winkler \\
Burt Zhang \\
\end{tabular}

\begin{tabular}{l}
\multicolumn{1}{c}{ Organization } \\
\hline BOC Process Systems \\
Dynacs Engineering \\
Oak Ridge National Lab \\
Stirling Technologies \\
NASA \\
Cryomech \\
EPRI \\
Air Products \& Chemicals \\
BOC Gases \\
Detroit Edison \\
Pirelli Cables North America \\
Leybold Cryogenics \\
PHPK Technologies \\
BOC Gases \\
General Atomics \\
NASA \\
APD Cryogenics \\
Mesoscopic Devices \\
NRL (retired) \\
NIST \\
ABB \\
DuPont \\
Praxair \\
Oak Ridge National Lab \\
Boeing Phantom \\
American Superconductor \\
BOC Process Systems \\
Praxair \\
NHMFL/Florida State University \\
Air Products \& Chemicals \\
Reliance Electric \\
\end{tabular}

\section{Observers}

$\begin{array}{ll}\text { James Daley } & \text { DOE } \\ \text { Joe Mulholland } & \text { DOE } \\ \text { Karen Thompson } & \text { NASA }\end{array}$

Facilitator: Joe Badin, Energetics, Incorporated

Note Taker: Tom Sheahen, Argonne National Lab 
U.S. Department of Energy Superconductivity Program for Electric Systems

\section{Cryogenics Vision for HTS Electric Systems Meeting}

July 27,1999

\section{DEFINITIONS}

\section{KEY DRIVERS}

These are the factors, conditions, possibilities, issues, trends, problems, and opportunities that will determine the future of the cryogenic refrigerator industry as a system supplier for commercially acceptable HTS electric power equipment over the next 20 years. Key drivers affect markets, technologies, and government policies. They impact the decision making of vendors, developers, installers, and users of new specific product lines. In retrospect, that is standing in the future and looking back in time, the key drivers will have been the factors that affected the development and deployment of cryogenic systems for HTS electric equipment the most.

\section{VISION}

At its simplest level, a vision is the answer to the question, "What kind of future do we want to create for the cryogenic refrigerator industry that will enable the widespread deployment of HTS electric power equipment?" The best visions are exhilarating. They motivate. They inspire. They create spark and lift organizations out of the mundane and foster commitment and risk taking. When people truly share a vision they are connected, bound together by a common aspiration. We are creating a common vision that will be shared by cryogenic system suppliers and HTS electric equipment developers. Visions reflect an "end-point", not the process of getting there. Vision statements are clear, concise, and to the point. They are specific and quantitative, but not overly so. They paint a picture of the future that stretches thinking about what could be but do not go beyond what realistically could be reached.

\section{STRATEGIC GOALS}

These are concrete, specific, and measurable. They answer the question, "What do we need to accomplish to reach our vision for the cryogenic refrigerator industry as a system supplier for commercially acceptable HTS electric power equipment?" They address the most important levers for accomplishing action including technology development initiatives, market deployment strategies, and government policies. They establish performance targets to guide the development of roadmaps and action plans. They are used to track progress toward achievement of the vision. They address the most significant policy, market, and technology barriers to the development and deployment of cryogenic systems. They include an action, outcome, and completion date. 


\section{What Are the Critical Factors in a Shared Vision Statement for Successful Future Commercialization?}

- One vision: On-site machine that produces cryogenic fluid $\left(\mathrm{N}_{2}, \mathrm{He}\right)$

- Cooling

- $\mathrm{LN}_{2}$ or mechanical

Do not lock in one now

- Market! Who will buy it?

- Cooling requirements vs. market size (applications)

- What does customer want to buy? Cold!

- Equipment suppliers: Service!

- Utilities are not monolithic - Business models

- Providing $\mathrm{LN}_{2}$ on site - Automatic startup

- What should critical infrastructure look like?

- What proof will utilities require before widespread deployment

- Reliability, maintenance interval

- Utility wants to buy a system

- Societal issues often drive utilities

- What is an acceptable system?

'- Requirements

- Specifications

- Reliability systems approach between vendor and customer

- Reliability is more important than temperature

- Any system must be "bulletproof"

- Safety

- Low cost maintenance scheduled similar to utilities
- Variable load

- What is the maintenance cycle?

- Electronic example:

- Base station

- 3-5 years maintenance

- Temperature (operating) $77 \mathrm{~K}$ below/above is major break point

- 10 years out $\mathrm{T}>80 \mathrm{~K}$

- NASA: safety, reliability, efficiency

- NASA: Cost is not important but is a consideration

- 2015? 2020? Cryocoolers

- Transformers 10 years (window of opportunity)

- Long-time between

- Maintenance

- Failure

- Requirements

- Unmanned

- Simple

- Future efficiency:

- $30 \%$ Carnot Efficiency

- $40 \%$ Carnot Efficiency

- Scale is a critical factor

- Hybrid systems $\left(\mathrm{LN}_{2}\right.$ and cryocoolers) enhance reliability

- $\mathrm{LN}_{2}$ is not the only temperature range of interest

- 77K Cables

- 30K Motors generators

- Heat exchange to air ambient $\mathrm{T}:-5^{\circ} \mathrm{C}<\mathrm{T}<75^{\circ} \mathrm{C}$

- Magnets operate near 30K; cables operate near $77 \mathrm{~K}$

- Compact extended range (variable load)
- Standardization on sizes (large markets)

- Size/real estate of cryogenic system

- System integration

- Cost-effectiveness trades against

- Reliability

- Delivery

- Service

- Transparent operation to the user

- Hybrid vs. non-redundancy

- $\mathrm{LN}_{2}$ hazardous material? Perception!

- Optimizing cryocoolers for each application

- Standardization is related to safety

- $60,000 \mathrm{~W}$ cooling in a cable system

- Cryocoolers need a generic design (modular?)

- Central facility for $\mathrm{LN}_{2} \mathrm{R} \& \mathrm{D}$ (universities, labs, industry) 
What Cryogenic System Goals Are Needed to Meet Future Commercial HTS Equipment Requirements?

\begin{tabular}{|c|c|}
\hline Cost & $\begin{array}{l}\text { - Cost } \leq 10 \% \text { of total system cost } \\
\text { - } \$ 8 \mathrm{~K} \text { for } 30 \mathrm{~K}, 60 \mathrm{~W} \text { (A.S.C.) } \\
\text { - } 600 \mathrm{~W} @ 70 \mathrm{~K} \text { (A.S.C.) }\end{array}$ \\
\hline EFFICIENCY & - Efficiency Goal: 30-40\% Carnot Efficiency \\
\hline $\begin{array}{l}\text { VARIABLE LOADS AND } \\
\text { DEMANDS }\end{array}$ & - Design point: $-50 \%+30 \%$ \\
\hline TEMPERATURE (TOP) & - Operating temperature $65<\mathrm{T}<85 \mathrm{~K}$ (cable) \\
\hline MARKET & $\begin{array}{l}\text { - } 100-150 \text { units/yr with input of } 40-60 \mathrm{~kW}(2004) \\
\text { - Cryocooler for motors: many units needed to create market } \\
\text { - Market size } \$ 10-\$ 100 \text { million per year }\end{array}$ \\
\hline $\begin{array}{l}\text { FAIL-SAFE } \\
\text { PERFORMANCE }\end{array}$ & $\begin{array}{l}\text { - Reliability, redundancy, backup } \\
\text { - Utility wants dístributed transmission systems }\end{array}$ \\
\hline COMPLEXITY & $\begin{array}{l}\text { - Avoid complexity in hardware (software complexity - ok) } \\
\text { - Modular systems for scheduled maintenance } \\
\text { - Simplicity of training - standard skills }\end{array}$ \\
\hline RELIABILITY & $\begin{array}{l}\text { - Maintenance cycle } \\
\text { - Maintenance motors: Annual } \\
\text { - Maintenance cable transformers: } 5-10 \text { years } \\
\text { - System transparent to the end user } \\
\text { - Unscheduled down time is very costly }\end{array}$ \\
\hline SAFETY & - "Zero time loss" accident goal \\
\hline FLEXIBILITY & - Ability to use different cryocoolers \\
\hline COMPACTNESS & - Quick change out \\
\hline MONITOR \& CONTROL & - Remote monitoring and control \\
\hline PERFORMANCE & - Cryocoolers vs. liquid systems \\
\hline
\end{tabular}




\section{What R\&D Activities Are Needed?}

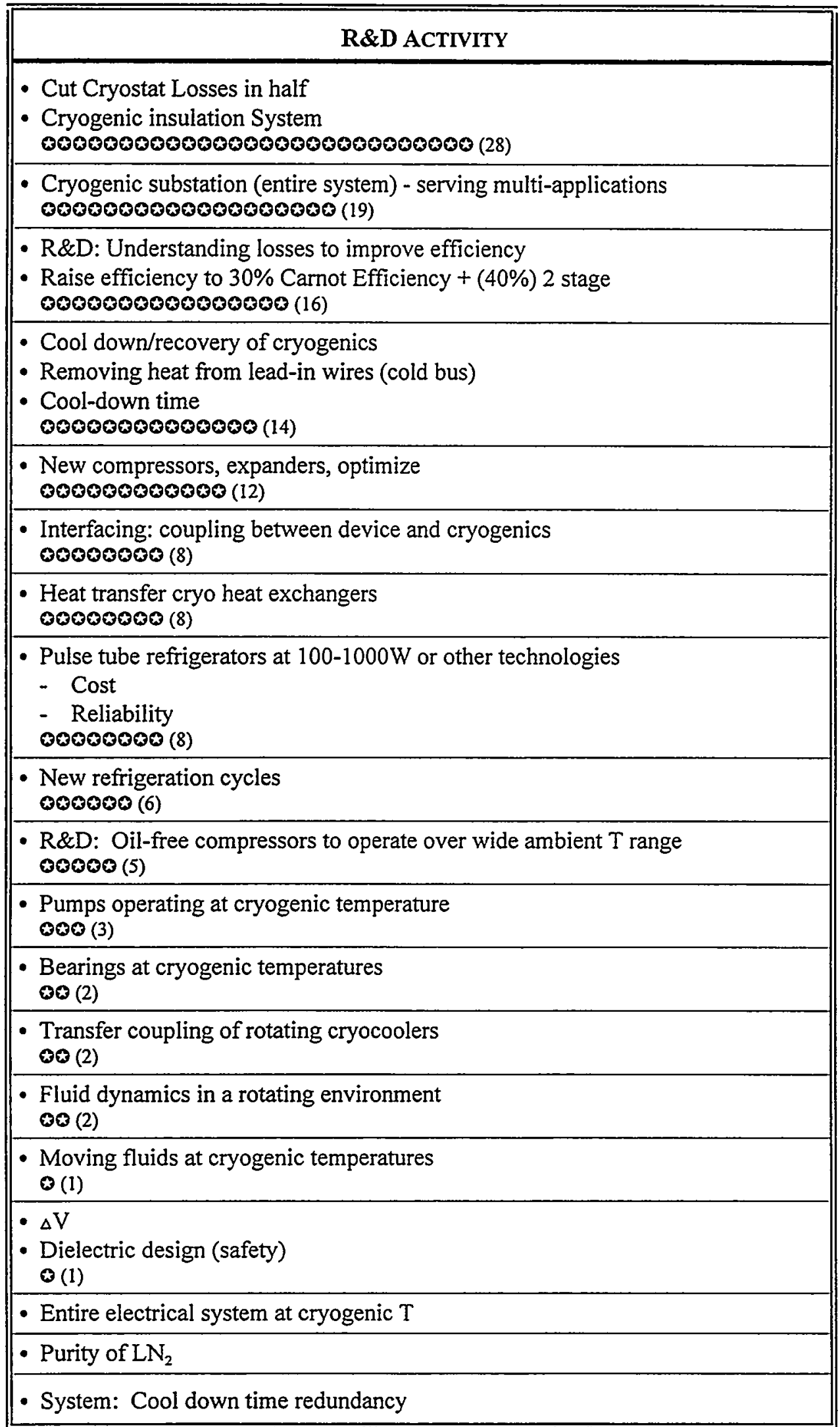


What R\&D Partnership Roles Can Be Identified?

\begin{tabular}{|c|c|}
\hline HIGH-PRIORITY R\&D ACTIVITY & GOVERNMENT ROLE \\
\hline 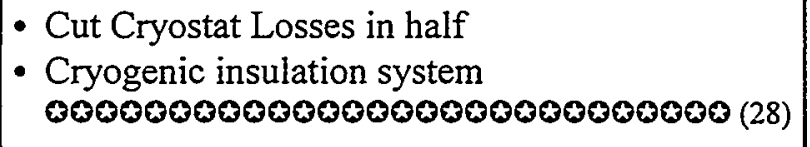 & $\begin{array}{l}\text { - Measurement and characterization (losses) } \\
\text { - Fundamental studies that are applicable across } \\
\text { many systems }\end{array}$ \\
\hline 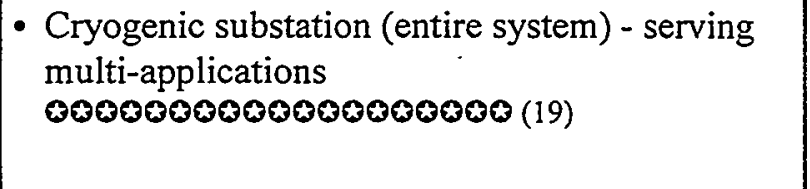 & $\begin{array}{l}\text { - Cryosubstation - government role is to: } \\
\text { - Reduce risk } \\
\text { - Interface } \\
\text { - Precompetitive R\&D }\end{array}$ \\
\hline 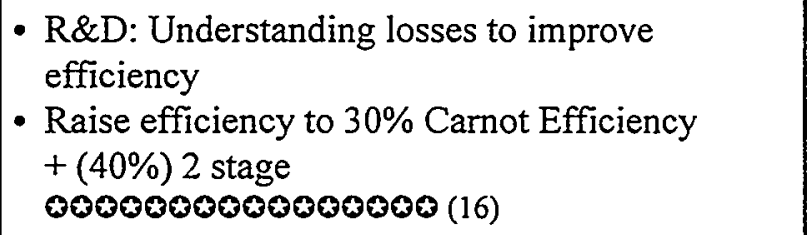 & $\begin{array}{l}\text { - Losses: Fundamental studies of losses } \\
\text { - Government role in getting the first one built }\end{array}$ \\
\hline 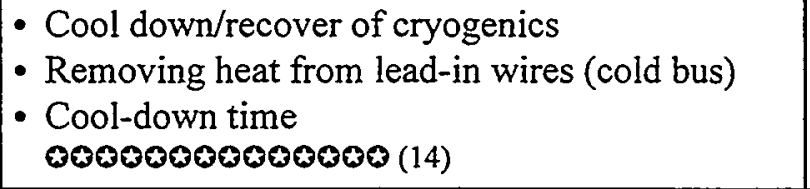 & - Development of fundamental knowledge \\
\hline 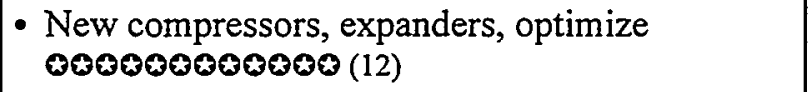 & - Prototype funding \\
\hline - General Cross-cutting R\&D & $\begin{array}{l}\text { - Funding ideas that are very different and very } \\
\text { risky }\end{array}$ \\
\hline
\end{tabular}




\section{Appendix A: Technology Roadmaps- Approaches and Lessons Learned \\ J. Badin}




\section{Technology Roadmaps}

Approaches and Lessons Learned

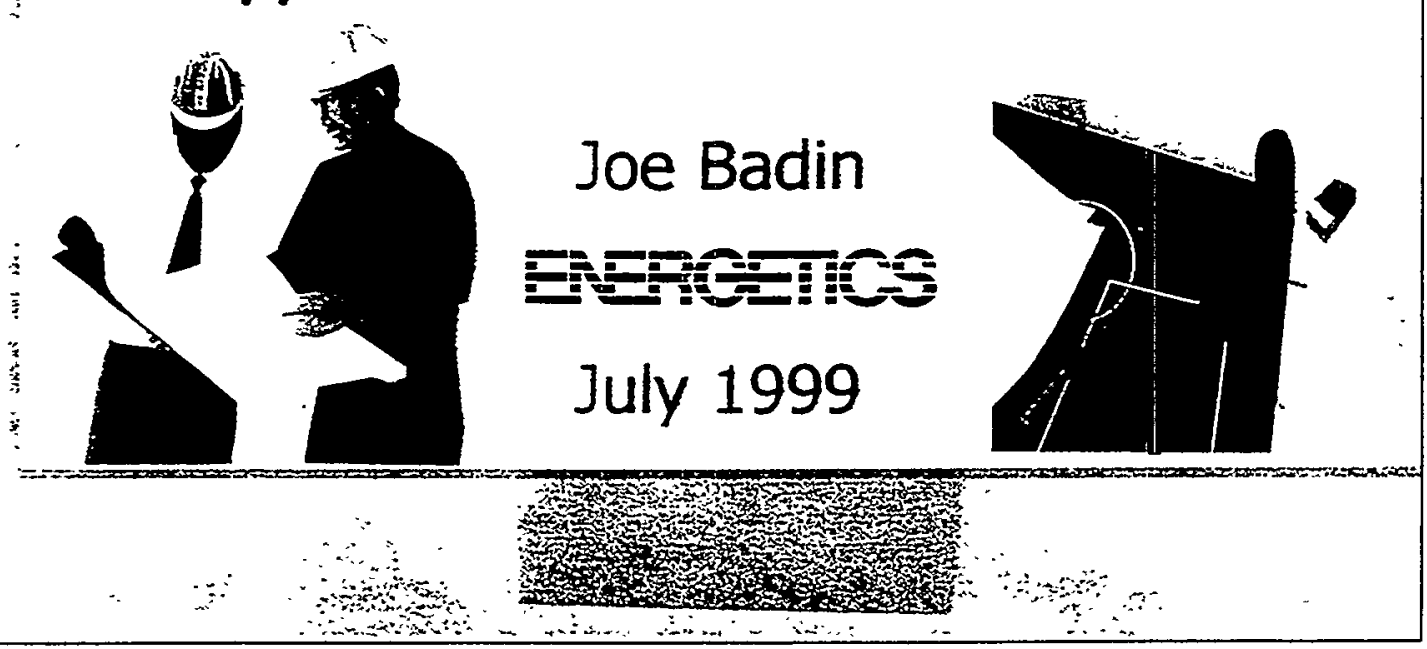

\section{Purpose}

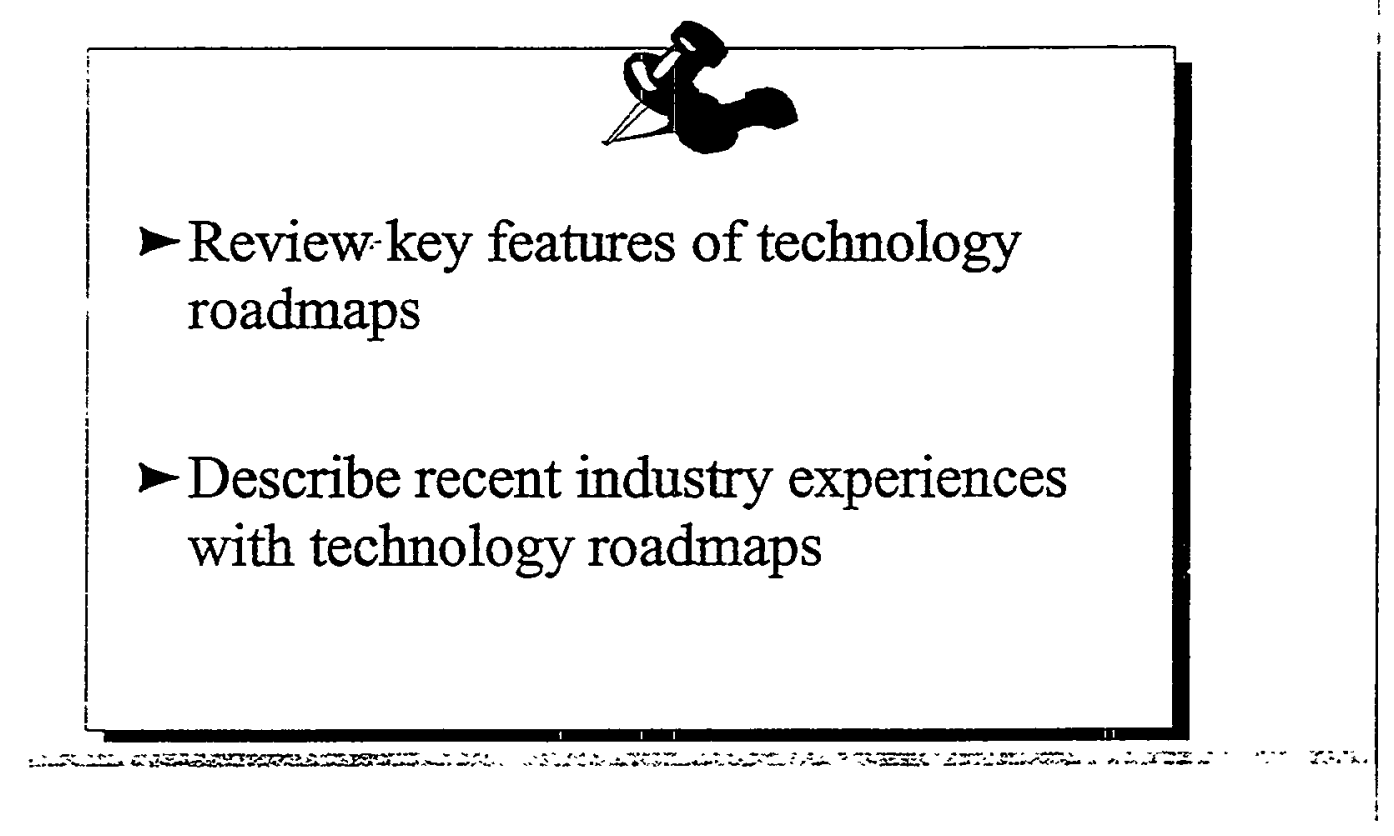




\section{Agenda}

-Why Are Technology Roadmaps Needed?

-What Is a Technology Roadmap?

-What Approaches Have Been Used?

-What Have Been the Lessons Learned?

\section{ॠदु?}

\section{Competitive Pressures}

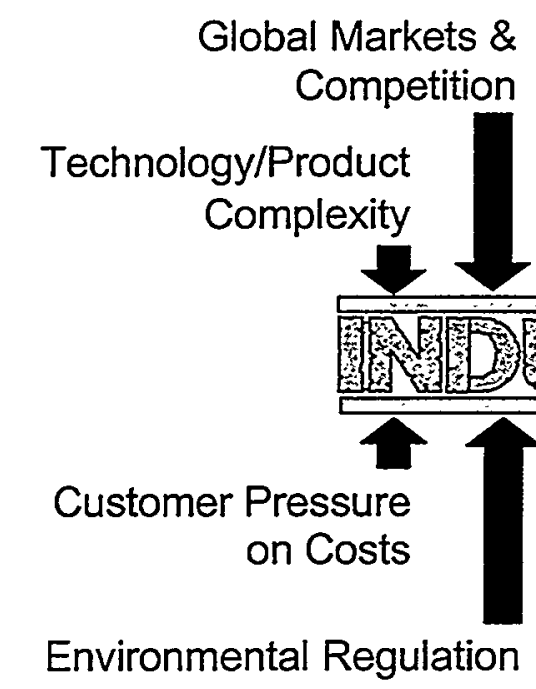

Technology/Product Complexity

Customer Pressure on Costs

Environmental Regulation 


\section{Technology Advantage in a Competitive Environment}

"In an era of man-made, brain-power industries, those who win will learn to play a new game with new rules requiring new strategies. Technology is making skill and knowledge the only sources of sustainable strategic advantage."

-- Lester Thurow, economist

\section{R\&D Leadership Has Shifted}

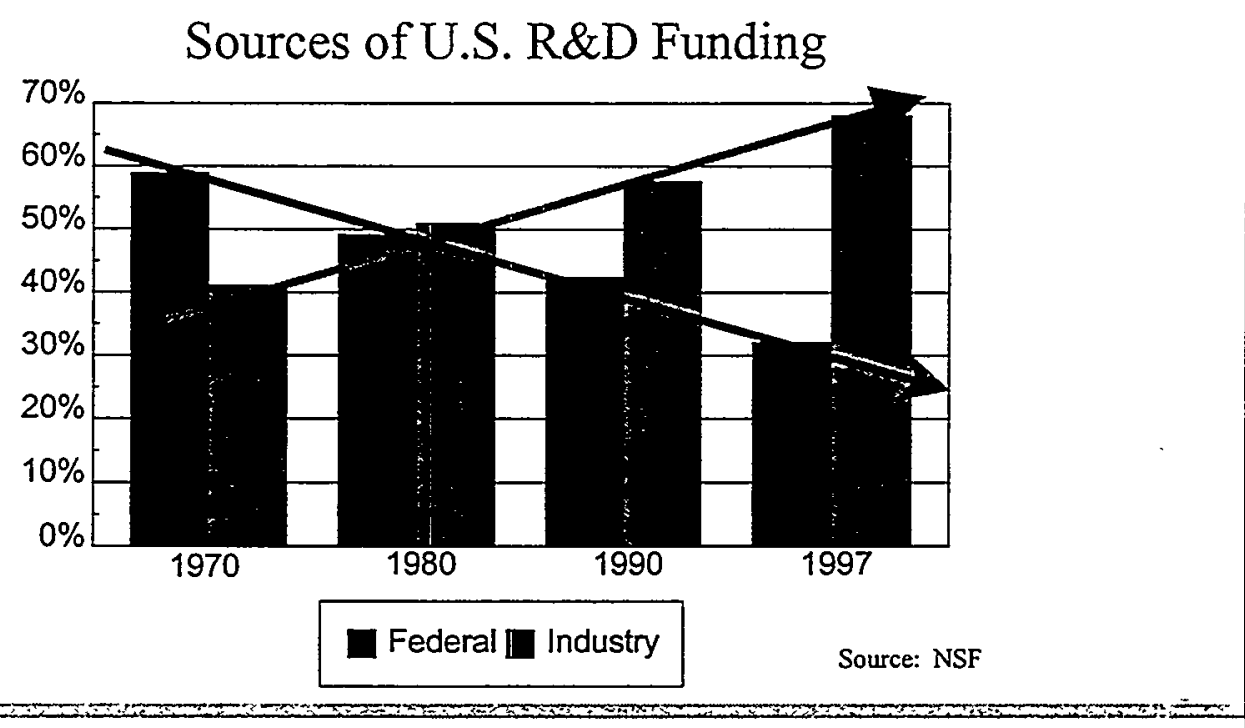




\section{R\&D Patterns Have Changed}

U.S. Research and Development Investment (\$ Billion 1996)

Source

Industry

113.5

Performer

Industry

134.2

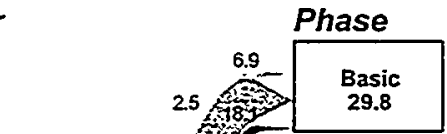

111
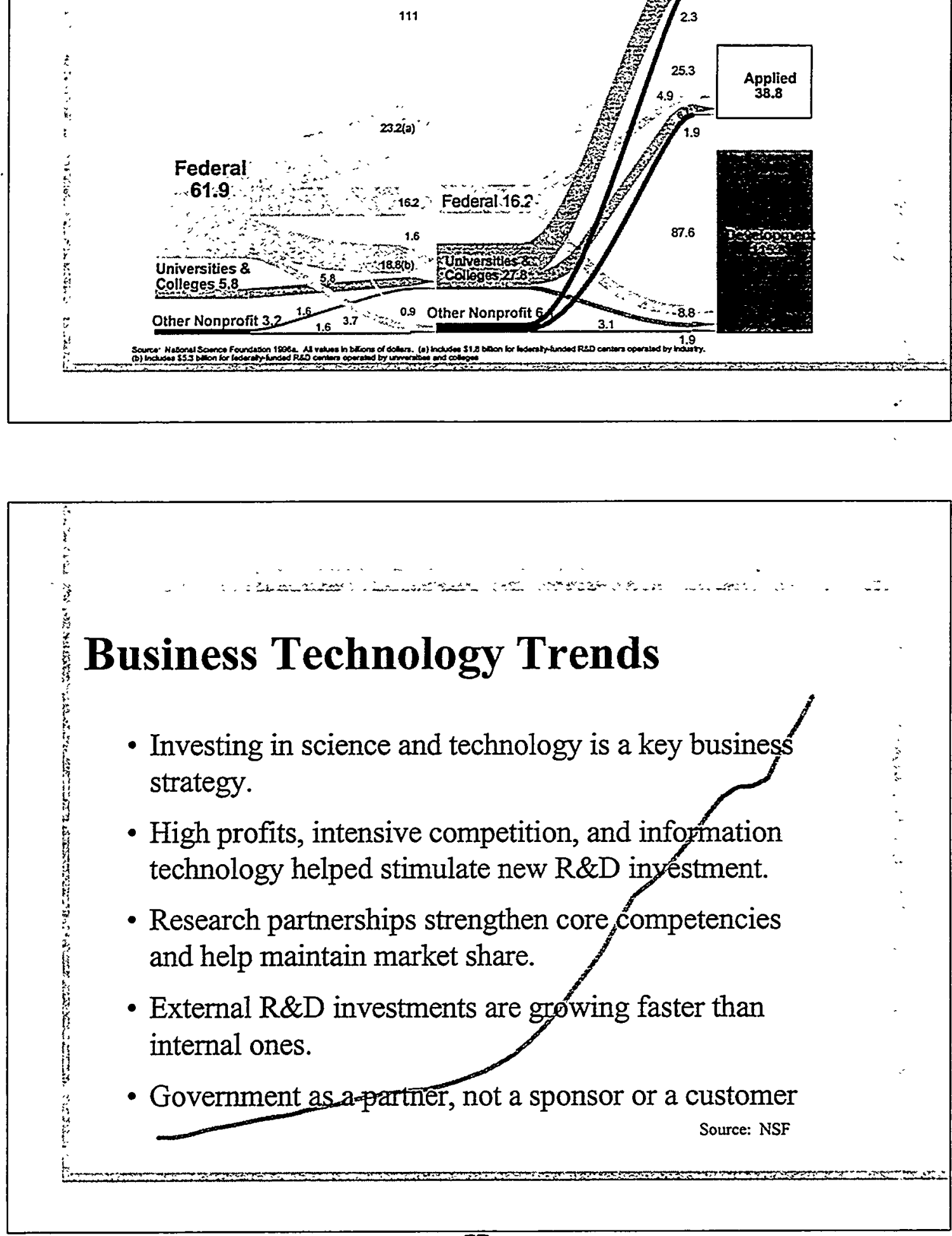


\section{Top 5 Problems for Technology Leaders}

Technology Issues

(1) Managing $\mathrm{R} \& \mathrm{D}$ for business growth

(2) Balancing long-term/short-term $\mathrm{R} \& \mathrm{D}$ objectives

3 Integrating technology planning with business strategy

(4) Making innovation happen

5 Managing global $R \& D$

\section{Agenda}

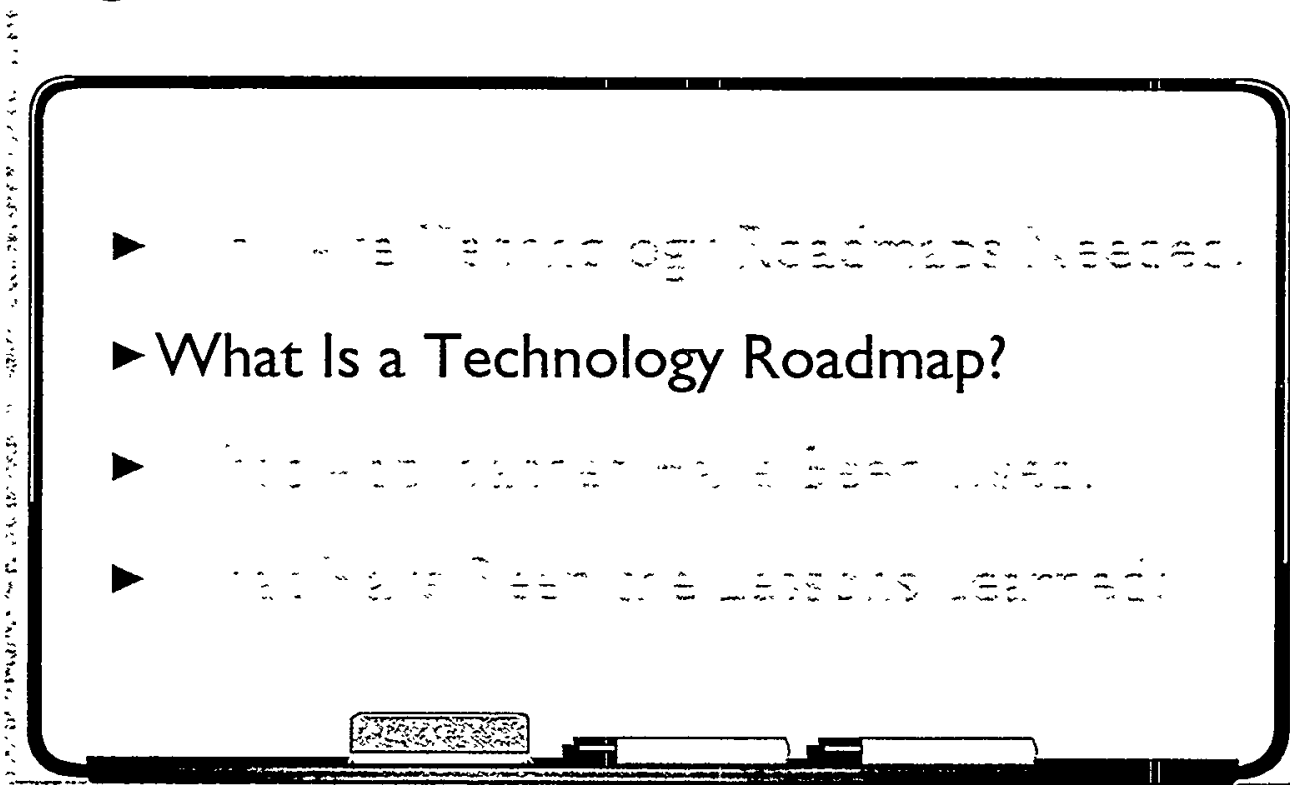




\section{Aligning Resources}

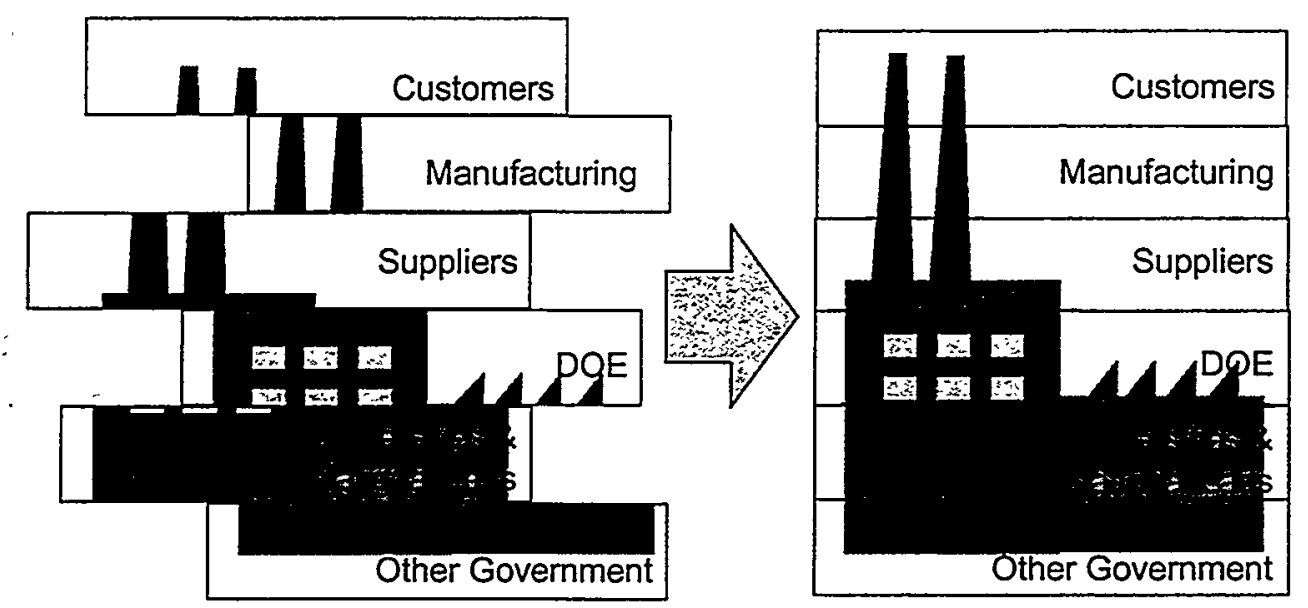

\section{OIT's Industries of the Future Process}

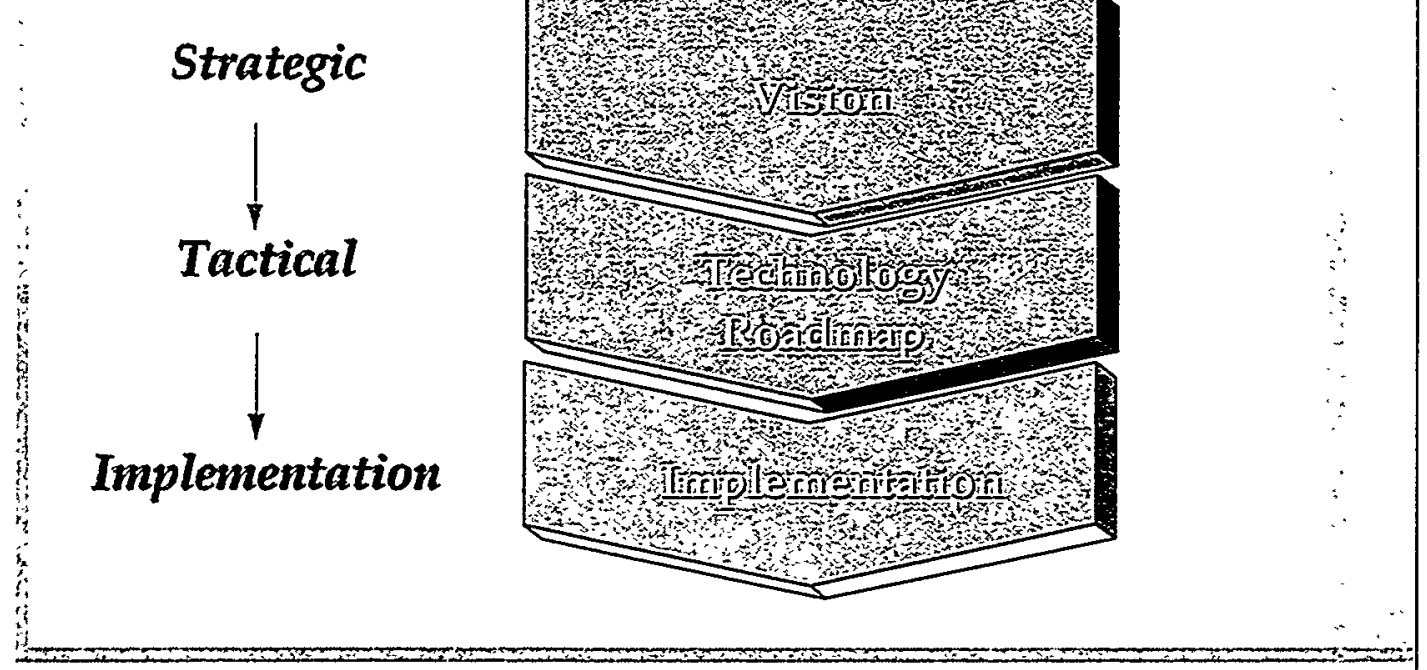




\section{Industries of the Future Strategy}

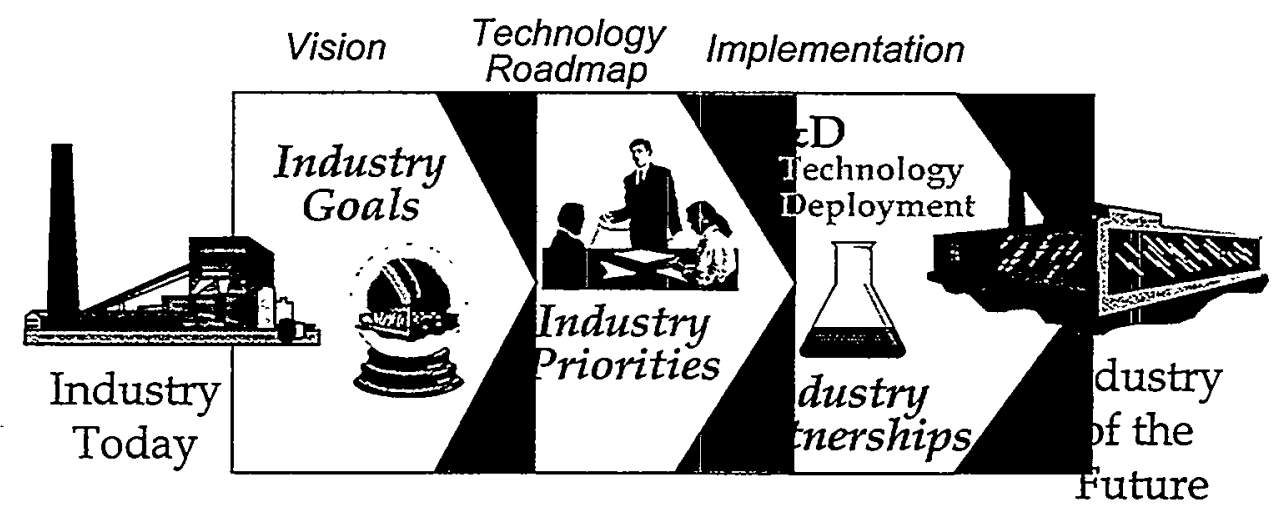

\section{Vision}

An industry-defined view of its desired future and the long-tern strategy to attain it.

Desired future state of the industry

- Strategic objectives and performance targets

- Market, business, and societal drivers

- Situation analysis of the industry

- Major challenges and barriers 


\section{Technology Roadmap}

A comprehensive technology strategy for achieving the goals of the Industry Vision.

- Technical performanree farirgets

- Assessment of current technologies

- Technology barriers, options, and pathways

- Research priorities organized by time frames

- Major milestones

\section{Implementation}

A multi-year action plan to implement a prioritized research agenda that accomplishes the Technology Roadmap.

- Industry priorities of proposed R\&D prof

- Integration with existing research efforts

- Capabilities of R\&D performers

- Project milestones and success indicators

- Resource requirements and commitments

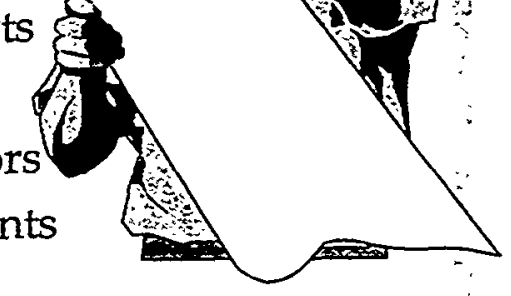




\section{Roles}

\section{Industry}

$\square$ Leads the process

$\square$ Identifies \& prioritizes technology needs

$\checkmark$ Develops implementation strategy

$\checkmark$ Commits resources

$\checkmark$ Conducts R\&D through partnerships

$\nabla$ Uses results
Government

$\checkmark$ Facilitates the process

$\nabla$ Coordinates industry participation

$\square$ Leverages government resources

$\square$ Shares project costs

$\square$ Provides access to the national laboratories

■Disseminates results

\section{Who Participates?}

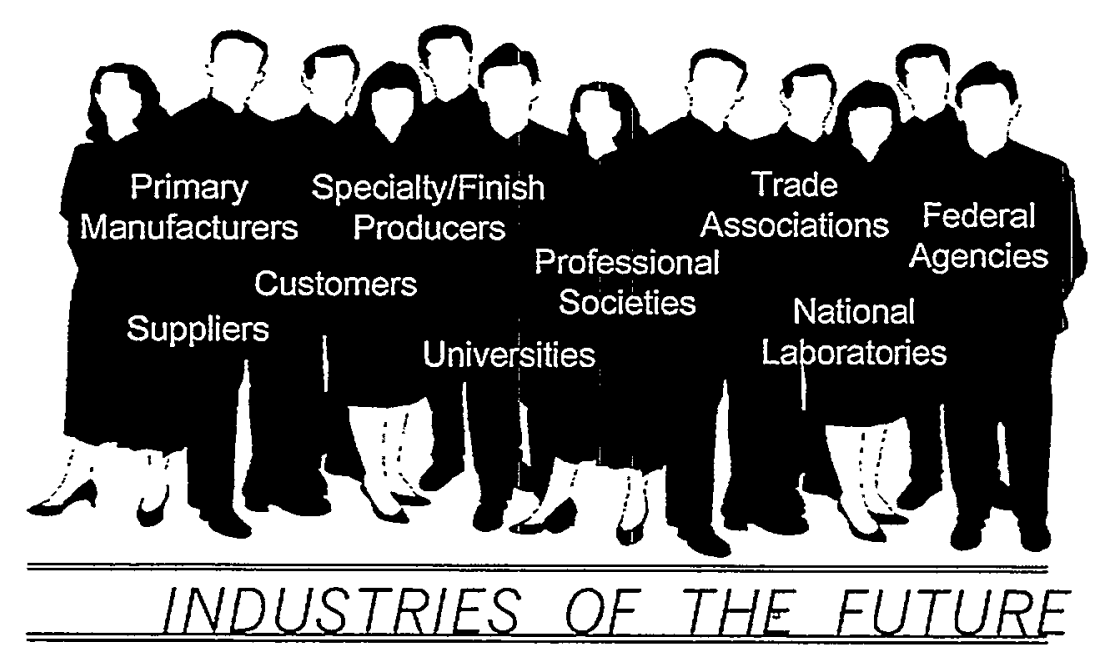




\section{What's in It for Your Company?}

$\square$ Conduct R\&D more efficiently

$\square \quad$ Reduce R\&D cost and risk

$\square$ Compete more effectively against competitors

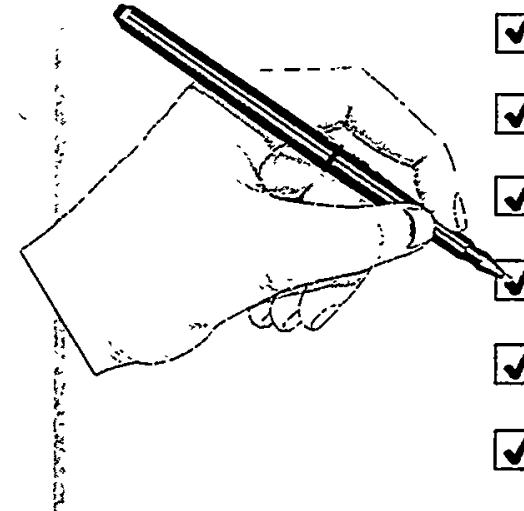

$\checkmark$ Broaden your knowledge base

$\checkmark$ Gain access to the national labs

Boost corporate image

$\square$ Capitalize on existing research

$\square$ Coordinated access to Federal R\&D

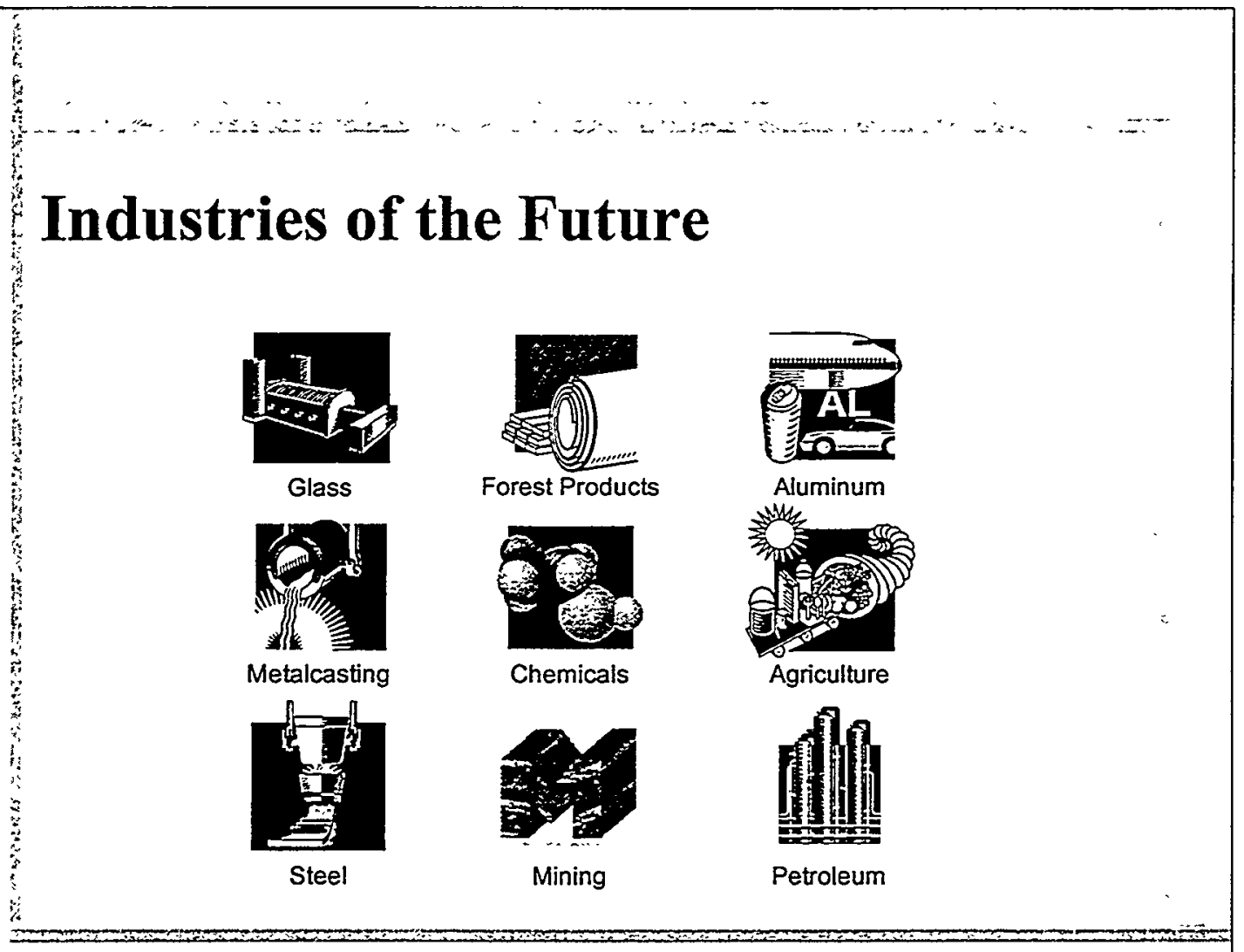




\section{Completed Visions, Workshops, and Roadmaps}

\begin{tabular}{|c|c|c|c|}
\hline- & & $\begin{array}{l}\because \\
\cdots \\
\cdots\end{array}$ & $\cdots:$ \\
\hline Aluminum & Yes & Yes (2) & Yes (3) \\
\hline Chemicals & Yes & Yes (7/4) & Yes (?) \\
\hline Forest Products & Yes & No & Yes \\
\hline Steel & Yes & No & Yes \\
\hline Glass & Yes & Yes & No \\
\hline Metalcasting & Yes & Yes & Yes \\
\hline Heat Treating & Yes & Yes & Yes \\
\hline Welding & Yes & No & No \\
\hline Forging & Yes & Yes & Yes \\
\hline Bio-Based Renewables & Yes & Yes & No \\
\hline Mining & Yes & Yes & No \\
\hline Combustion & Yes & Yes & Yes \\
\hline Materials & Yes & Yes (2) & Yes \\
\hline
\end{tabular}

\section{Roadmap Logic}

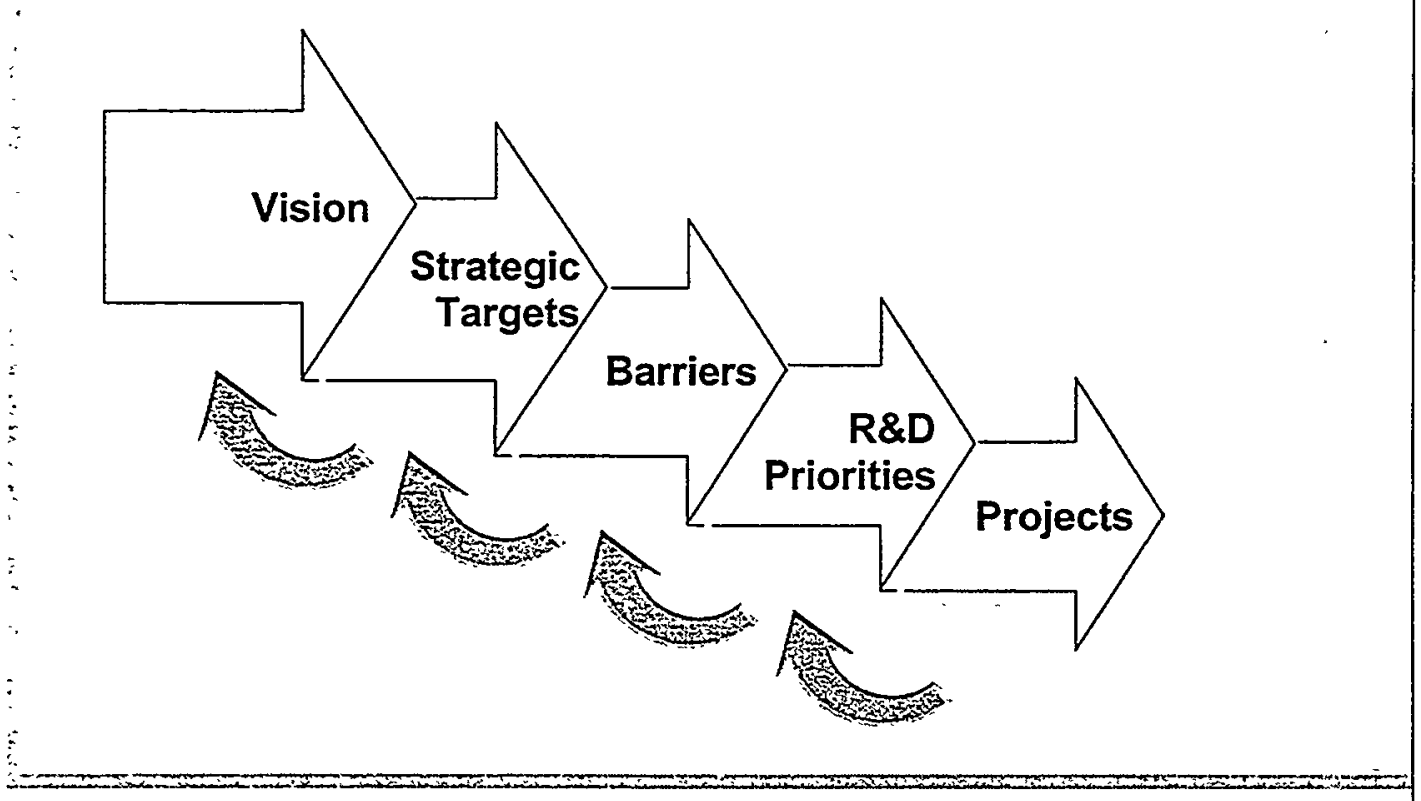




\section{Special Features of Technology}

\section{Roadmaps for Industry}

- Broad representation and participation

- Multiple products, processes, and markets

- Limited ability to quantify goals and benefits

- Technology needs defined broadly

- Difficult to integrate and link R\&D activities

- Often requires additional roadmaps for priority areas

- Very powerful -- widespread impact

\section{A Good Roadmap Should ...}

- Outline technology and research requirements to achieve industry goals and targets

- Provide enough detail to quickly implement research solicitations and projects

- Reflect the concerns of the entire industry, including customers and suppliers

- Draw upon previous workshops, surveys, analyses, and studies of the industry

- Be strategic, clear, and easy to follow 


\section{Elements of Successful Roadmaps}

- Set all performance targets

- Indicate near-, mid-, and long-term research needs

- Explain relationships among research activities

- Identify lead responsibility for funding research activities

- Define the roles of customers, suppliers, government agencies, universities, national laboratories, states, industry associations, and manufacturers in accomplishing the roadmap.

- Quantify research benefits and set performance measures

- Show relationship to other industry visions

\section{How Can the Roadmap Help Me?}

- Guide research priorities within the industry

- Confirm research needs within your company

- Align research within industry, academia, and government

- Strengthen leadership on environmental issues

- Provide a "technical marketing" tool that helps government programs

- Provide a communications tool to suppliers and customers 


\section{Workshops}

An effective way to identify research needs and priorities and to build consensus.

- Draw from previous workshops and surveys -- no need to ask the same questions

- Include a representative cross-section of industry participants

- Have a very specific purpose in mind

- set/confirm technical performance targets

- identify technical barriers

- set research priorities (various approaches)

- gather inputs to fill specific gaps

\section{Agenda}

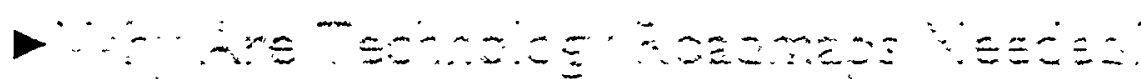

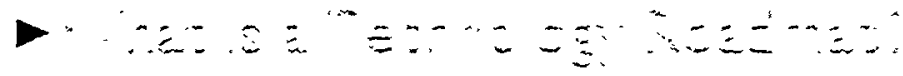

-What Approaches Have Been Used?

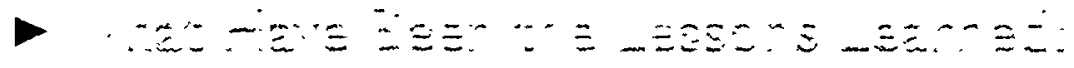

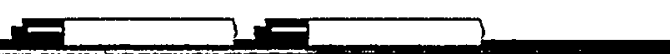




\section{Basic Process Steps}

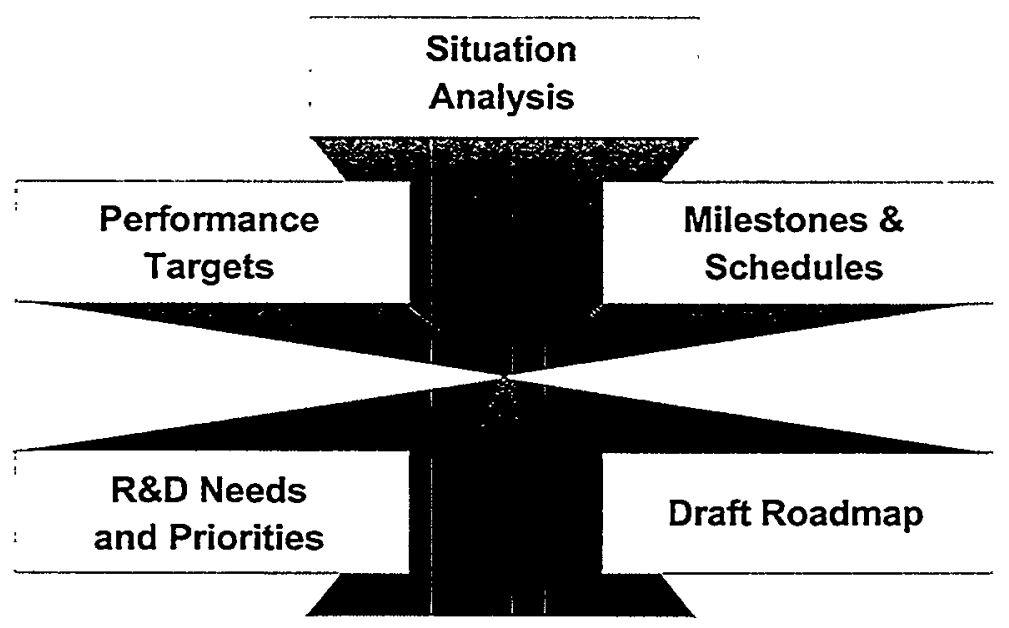

Final

Roadmap

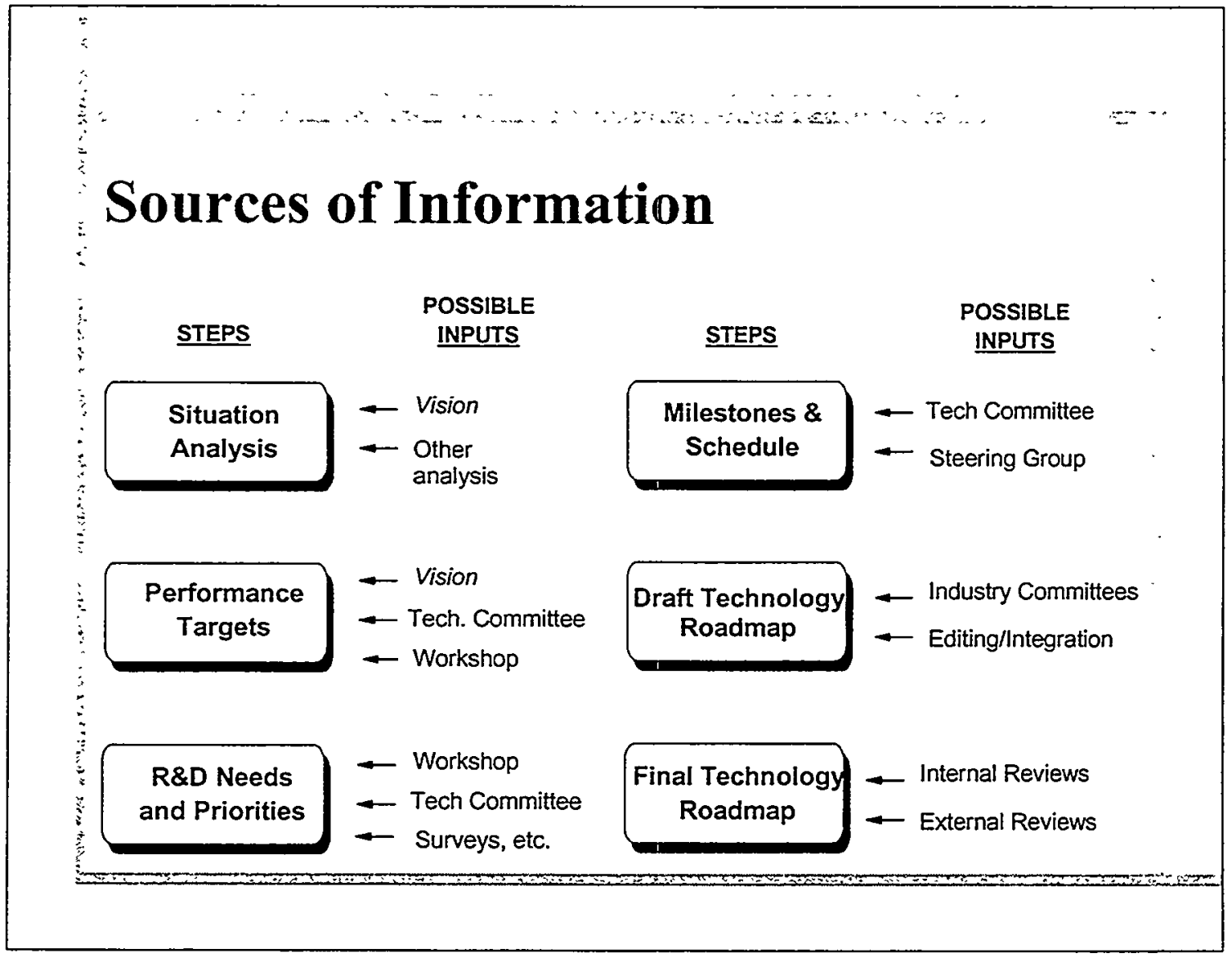




\section{Aluminum Industry Experience}
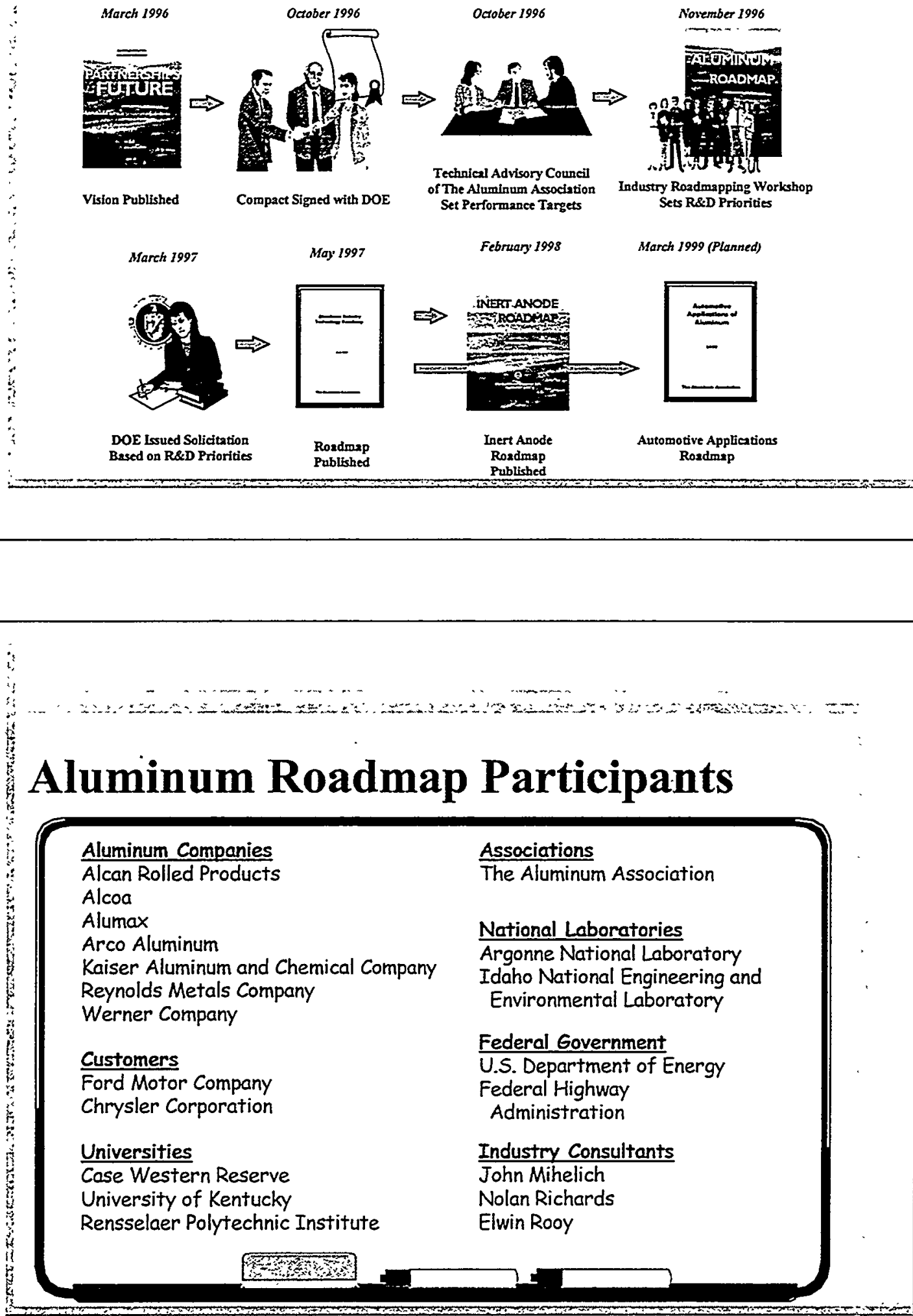


\section{Forest Products Industry Experience}
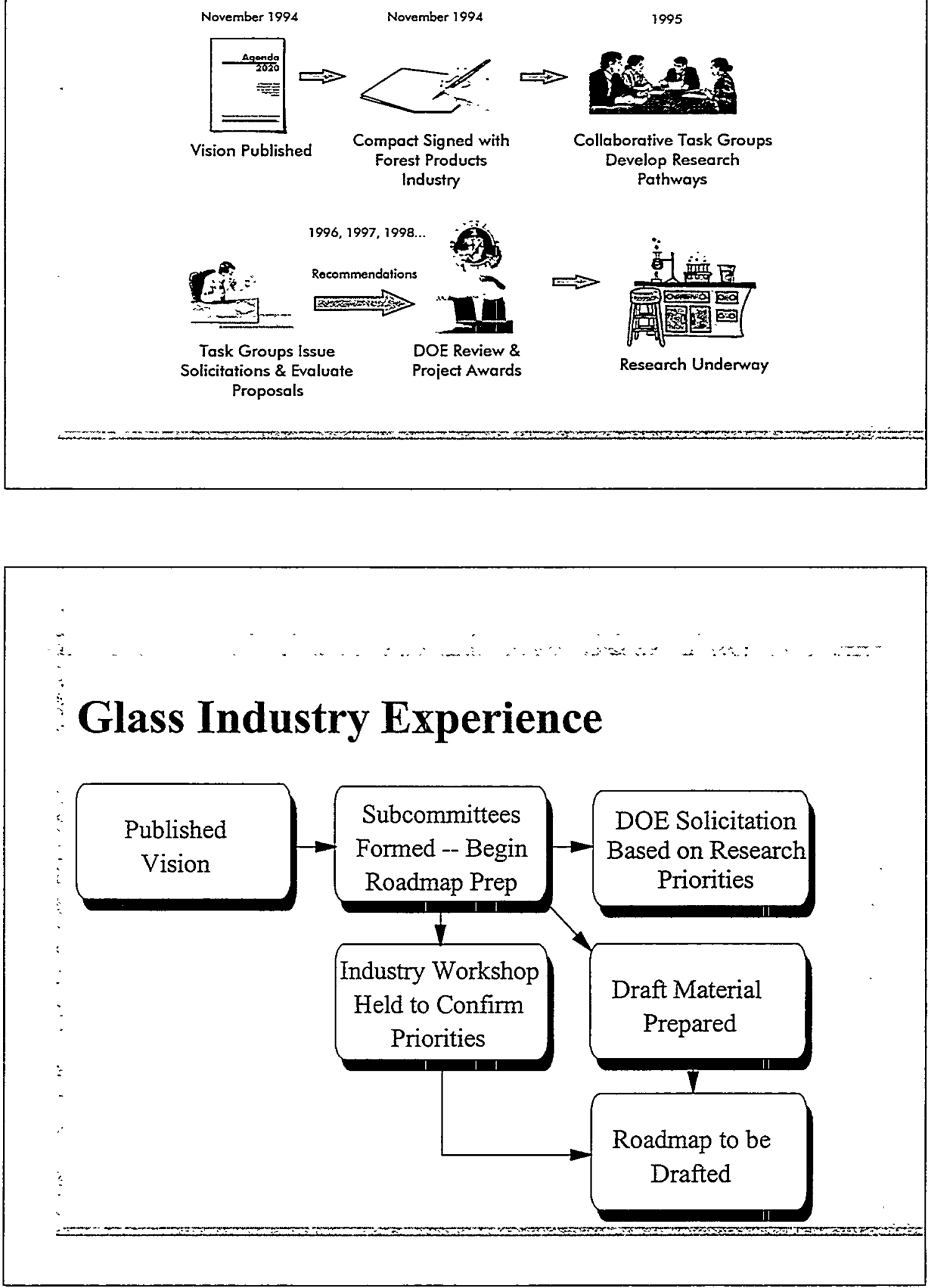


\section{Glass Workshop Participants}
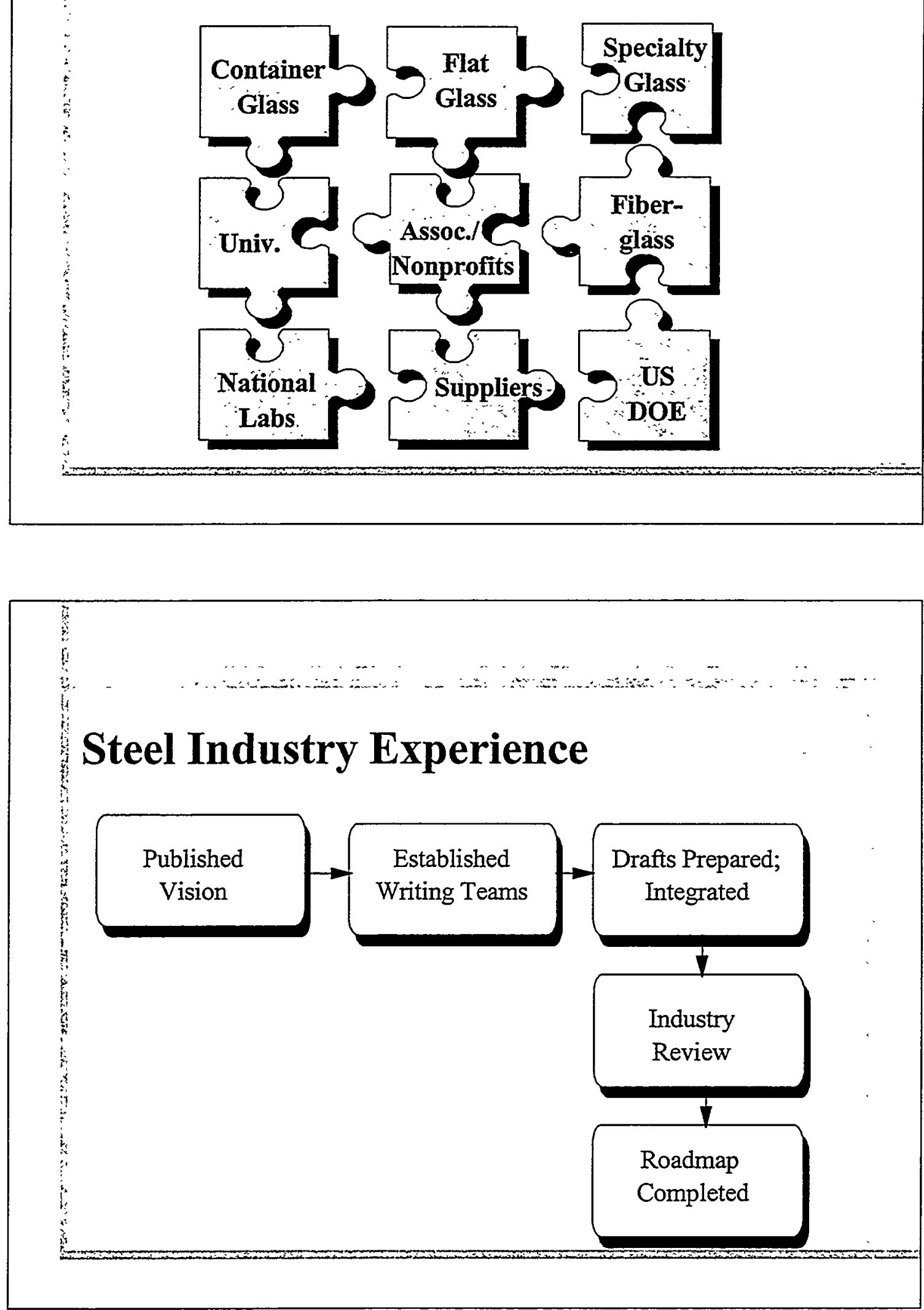


\section{Metalcasting Industry Experience}

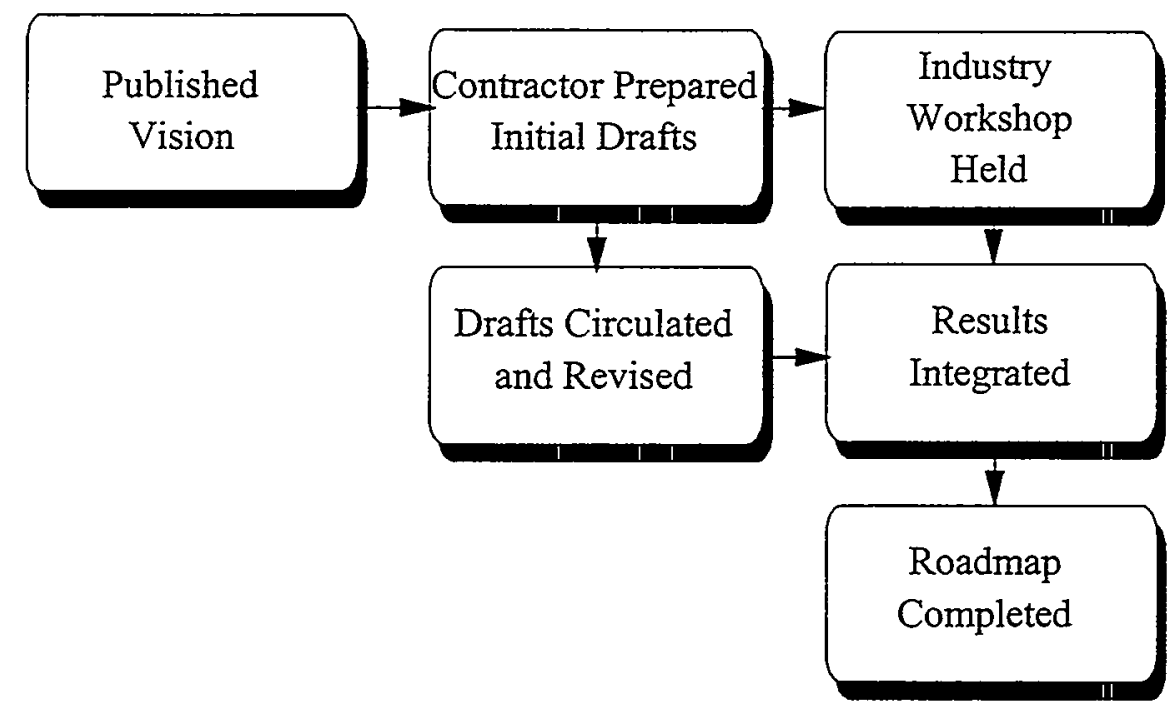

\section{Forging Partnerships}

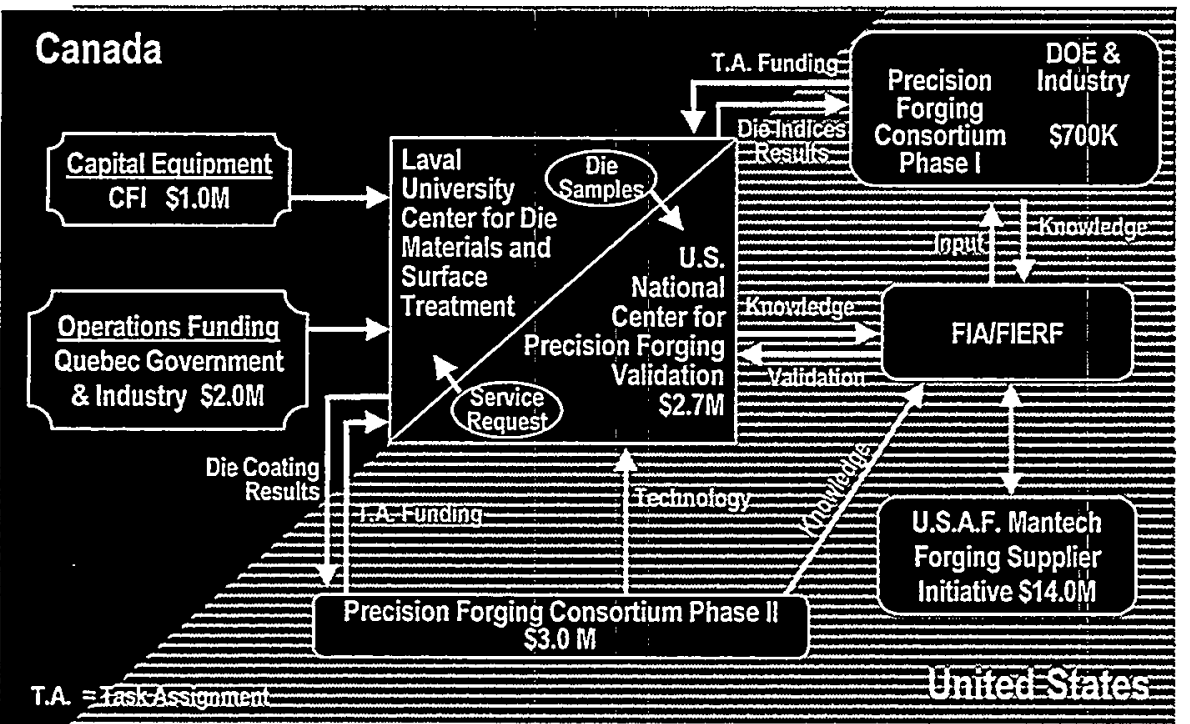



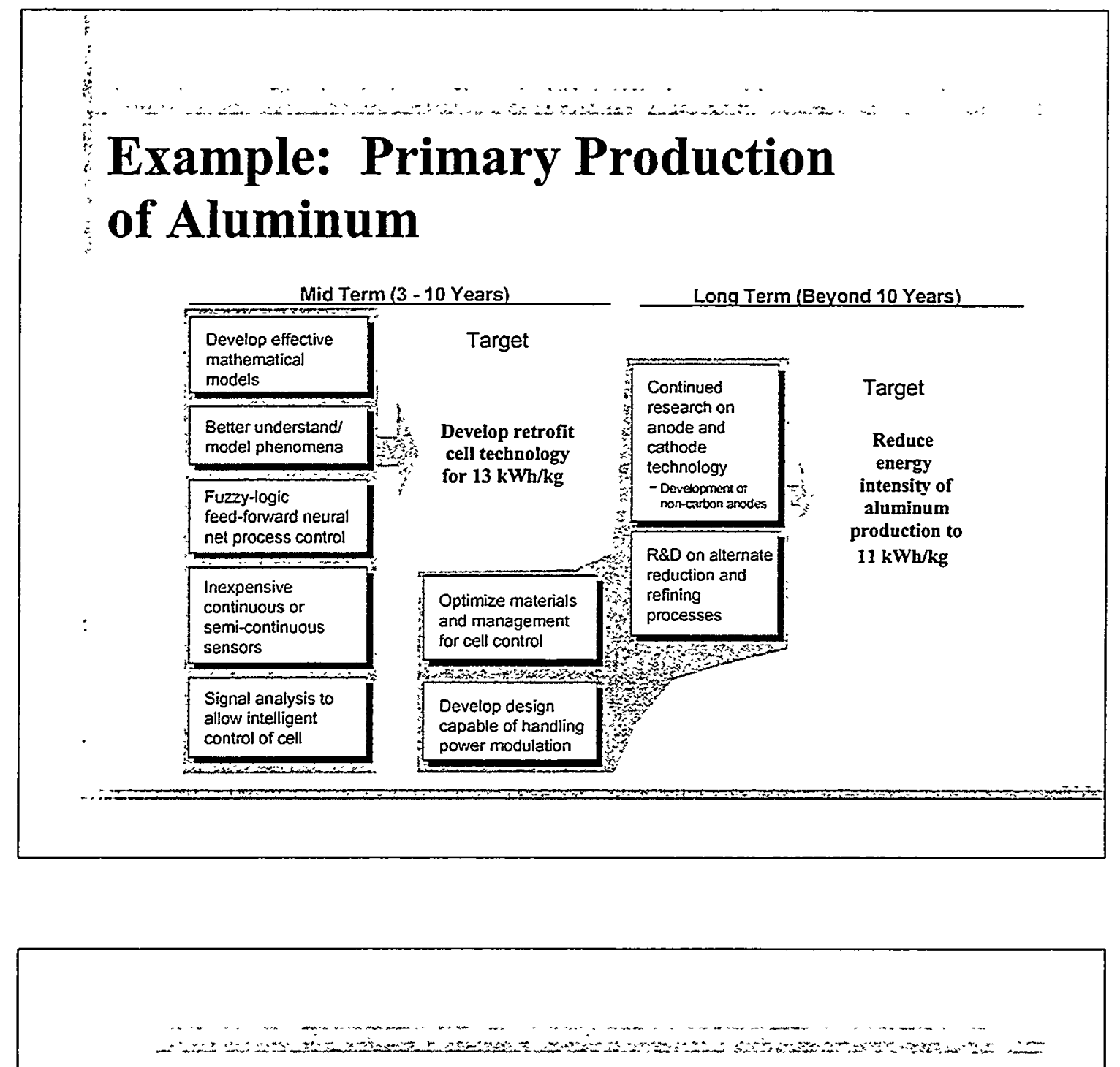

\section{Example: Combustion} Roadmap

\section{Industy Need: Environmental Quality and Greenhouse Gases}

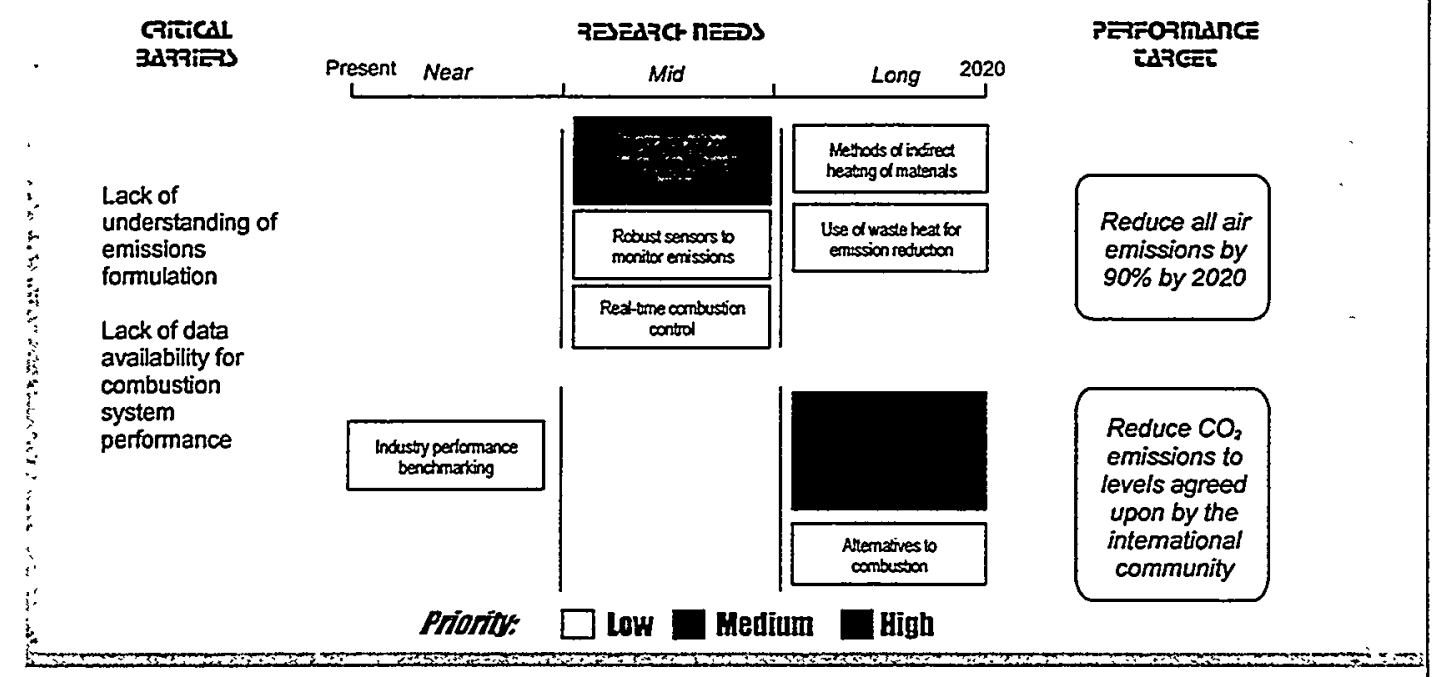




\section{Agenda}

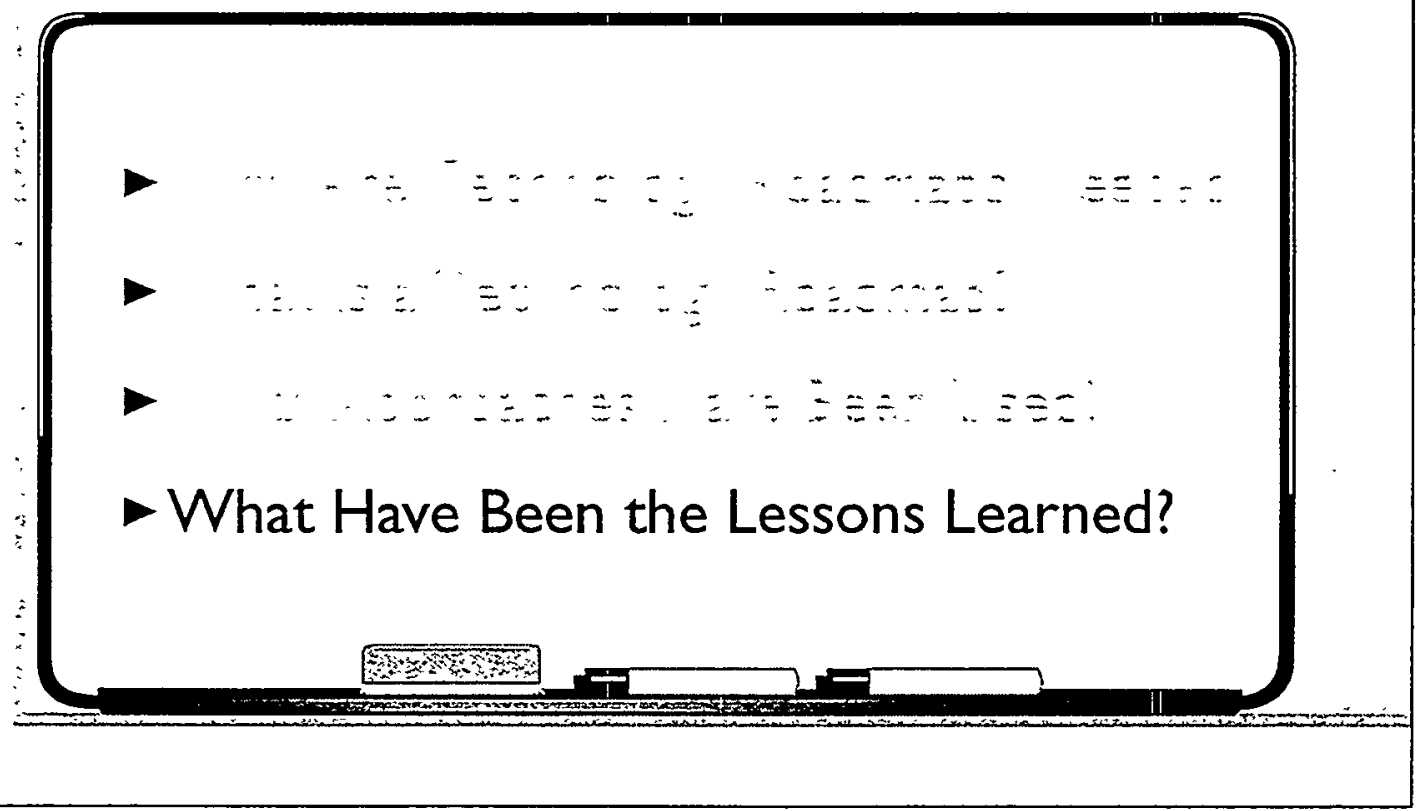

\section{Lessons Learned}

- Define the final roadmap and work backward

- Don't make up the process as you go along

- Pay attention to the review cycles

- Make the roadmap readable for everyone

- Show how roadmap activities will achieve vision goal

- A workshop is not a roadmap

- Workshops can be useful but you only have one shot

- Get the right people involved

- Don't waste people's time 


\section{Secrets of Successful Roadmaps}

\section{In The Process}

- Include the right people

- Begin to build partnerships

- Design a manageable process

- Carefully plan the review cycle

\section{Secrets of Successful Roadmaps}

In The Product

- Clearly define performance targets

- Show relationships among research activities

- Define the roles of customers, suppliers, government agencies, universities, national laboratories, states, industry associations, and manufacturers

- Quantify research benefits and set performance measures 


\section{Key Issues and Next Steps}

- Develop an overall process and rough schedule

- Identify participants in the technology roadmap process

- Define performance targets and technical objectives

- Conduct analysis of trends, drivers, current technologies, barriers, etc.

- Hold a workshop to lay out research needs and priorities?

- Obtain buy-in from customers, suppliers, and research community

- Coordinate/integrate with other industry visions 


\section{List of Attendees}




\section{List OF ATTENDEES}

Tim Atkinson

Manger, Technology Best Practices

BOX Process Systems

575 Mountain Avenue

Murray Hill, NJ 07974-2082

phone: (908) 771-1526

fax: (908) 771-4838

e-mail: tim.atkinson@processplants.boc.com

Stan Augustynowicz

Senior Principal Investigator

Dynacs Engineering Company, Inc.

DNX-3

Kennedy Space Center, FL 32899

phone: (407) 867-4440

fax: (407) 867-4424

e-mail: stan.augustynowiczz@ksc.nasa.gov

Joseph Badin

Assistant Vice President

Energetics, Incorporated

7164 Gateway Drive

Columbia, MD 21046

phone: (410) 953-6252

fax: (410) 290-0377

e-mail: jbadin@energetics.com

Mr. Jonathan A. Demko

Development Staff

Oak Ridge National Laboratory

P.O. Box 2009

Oak Ridge, TN 37831-6056

(423) 574-1469

Fax: (423) 574-0584

E-Mail: demkoja@ornl.gov

James Fesmire

Senior Engineer

National Aeronautics and Space Administration

MM-J2

Kennedy Space Center, FL 32899

phone: (407) 867-7969

fax: (407) 867-2758

e-mail: james.fesmire@ksc.nasa.gov
Paul M. Grant

Executive Scientist

Electric Power Research Institute

P.O. Box 10412

3412 Hillview Avenue

Palo Alto, CA 94303-0813

phone: (415) 855-2234

fax: (415) 855-2287

e-mail:pgrant@eprinet.epri.com

George Harriott

Research Associate

Global App. Dev. Advanced Tech

Air Products and Chemicals

7201 Hamilton Blvd.

Allentown, PA 18195-1501

phone: (610) 481-5303

fax: (610) 481-5136

e-mail: harriogm@apci.com

Michael Heil

Director

BOC Gases

575 Mountain Avenue, 3 East

Murray Hill, NJ 07974

phone: (908) 771-1474

fax: (908) 771-1709

e-mail: michael.heil@us.gases.boc.com

Jon Jipping

Principal Engineer

Detroit Edison

2000 Second Avenue

Detroit, MI 48226

phone: (313) 235-7806

fax: (313) 235-6619

e-mail: jippingj@dteenergy.com

Nathan Kelley

Development Engineer

Pirelli Cables North America

710 Industrial Drive

Lexington, SC 29072

phone: (803) 356-7762

fax: (803) 356-7765

e-mail: nathan.kelley@u.s. pirelli.com 
Peter Kerney

Manager Business Development

Leybold Cryogenics

25 Sagamine Park Road

Hudson, NH 03051

phone: (603) 595-3286

fax: (603) 595-3280

e-mail: 112201,1640@compuserve.com

Ken Kreinbrink

Vice President, Engineered Products and Systems

PHPK Technologies Inc.

535 Enterprise Drive

Westerville, OH 43081

phone: (614) 436-9114

fax: (614) $436-5816$

e-mail: info@phpk.com

Ron Lee

principal Engineer

BOC Gases

100 Mountain Road

Murray Hill, NJ 07974

phone: (808) 771-6244

fax: (908) 771-6488

e-mail: ron.lee@us.gtc.boc.com

\section{Eddie Leung}

Senior Program Manger

General Atomics

3550 General Atomics $\mathrm{Ct}$.

San Diego, CA 92121-1194

phone: (619) 455-4443

fax: (619) 455-4341

e-mail: eddie.leung@gat.com

Maria Littlefield

Chief, Mechanical \& Electrical GSE

National Aeronautics and Space Administration

MM-J2

Kennedy Space Center, FL 32899

phone: (407) 867-7373

fax: (407) 867-2758

e-mail: maria.littlefield-1@ksc.nasa.g

Jeffy Martin

President

Mesoscopic Devices, LLC

3400 Industrial Lane, Suite 7B

Broomfield, CO 80020

phone: (303) 466-6968

fax: (303) 466-6871

e-mail: jmartin@mesoscopic.com
Joe Mulholland

Director, Electric Delivery Systems

U.S. department of Energy

1000 Independence Avenue, SW, EE-10

Washington, DC 20585

phone: (202) 586-1491

fax: (202) 586-1640

e-mail: joseph.muylholland@ee.doe.gov

Martin Nisenoff

Naval Research Lab

4555 Overlook Avenue, SW, Code 86850

Washington, DC 20375-5343

phone: (202) 767-3099

fax: (202) 767-0455

e-mail: nisenoff@nrl.navy.mil

Dr. V.R. Ramanan

Executive Consulting Scientist

ABB-ETI

1021 Main Campus Drive

Raleigh, NC 27606

(919) 856-2423

Fax: (919) 856-2448

vr.v.ramanan@ustra.mail.abb.com

Dr. Christopher M. Rey

Project Manager, Magnets

E.I. DuPont De Nemours \& Co., Inc.

Experimental Station, E304/C119

Wilmington, $D E$ 19880-0304

(302) 695-9470

Fax: (302) 695-2721

E-Mail: christopher.m.rey@usa.dupont.com

John Royal

Manager

Praxair, Inc.

175 East Park Drive

Tonawanda, NY 14150-7891

phone: (716) 897-2617

fax: (716) 879-7091

e-mail:john_royal@praxair.com

Thomas Sheahen

President

Western Technology Inc.

305 West Side Drive, \#303

Gaithersburg, MD 20878-3052

phone: (301) 869-2628

fax: (301) 869-6844

e-mail: tsheahan@alum.mit.edu 
John Stovall

Research Staff

Oak Ridge National Laboratory

Building 3147, MS-6070

Oak Ridge, TN 37831-6070

phone: (423) 574-5198

fax: (423) 574-5227

e-mail: stovalljp@ornl.gov

Mike Strasik

Technical Fellow

Boeing Phantom

P.O. Box 3999, MS 78-09

Seattle, WA 98124

phone: (425) 237-7176

fax: (425) 234-2863

e-mail:michael.strasik@boeing.com

Karen Thompson

Manager of Technology Testbeds

National Aeronautics and Space Administration

MM-H

Kennedy Space Center, FL 32899

[hone: (407) 867-3327

fax: (407) $867-2960$

e-mail: karen.thompson-1@ksc.nasa.gov

Robert Thorogood

Engineering Fellow

BOC Process Systems

575 Mountain Avenue

Mur4ray Hill, NJ 07974-2082

phone: (908) 771-16793

fax: (908) 771-6040

e-mail: rob.thorogood@processplants.boc.com

Michael Troy

Director, Marketing \& New Business Development

Praxair, Inc.

39 Old Ridgebury Road

Danburey, CT 06810

phone: (203) 837-2334

fax: (203) 837-2737

e-mail: mike_troy@praxair.com

Steven Van Sciver

Director, Magnet Science \& Technology

National High Magnetic Field Laboratory

1800 E. Paul Dirac Drive

Tallahassee, FL 32310

phone: (904) 644-0998

fax: (904) 644-0867

e-mail: vnsciver@magnet.fsu.edu
Philip Winkler

Manager, Government Systems

Air Products and Chemicals

7201 Hamilton Boulevard

Allentown, PA 18195-1501

phone: (610) 481-4284

fax: (610) 481-2576

e-mail:winklepw@apci.com

Burt Zhang

Reliance Electric Company

24800 Tungsten Road

Cleveland, $\mathrm{OH} 44117$ 
ORNL/Sub/62X-SV815C/S1

\section{DISTRIBUTION}

1-30. Workshop Participants

31. Laboratory Records-RC

32-33. Office of Scientific and Technical Information, P. O. Box 62, Oak Ridge TN 37831

34-200. Energetics, Inc., 7164 Gateway Drive, Columbia MD 21046 